\title{
A Zebrafish Model of Myelodysplastic Syndrome Produced through tet2 Genomic Editing
}

\section{Citation}

Gjini, Evisa, Marc R. Mansour, Jeffry D. Sander, Nadine Moritz, Ashley T. Nguyen, Michiel Kesarsing, Emma Gans, et al. 2015. "A Zebrafish Model of Myelodysplastic Syndrome Produced through Tet2 Genomic Editing." Molecular and Cellular Biology 35 (5): 789-804. doi:10.1128/ MCB.00971-14.

\section{Permanent link}

http://nrs.harvard.edu/urn-3:HUL.InstRepos:41543090

\section{Terms of Use}

This article was downloaded from Harvard University's DASH repository, and is made available under the terms and conditions applicable to Other Posted Material, as set forth at http:// nrs.harvard.edu/urn-3:HUL.InstRepos:dash.current.terms-of-use\#LAA

\section{Share Your Story}

The Harvard community has made this article openly available.

Please share how this access benefits you. Submit a story.

Accessibility 


\title{
A Zebrafish Model of Myelodysplastic Syndrome Produced through tet2 Genomic Editing
}

\begin{abstract}
Evisa Gjini, ${ }^{a}$ Marc R. Mansour, ${ }^{\text {a,g }}$ Jeffry D. Sander, ${ }^{\text {b,c }}$ Nadine Moritz, ${ }^{a}$ Ashley T. Nguyen, ${ }^{a}$ Michiel Kesarsing, ${ }^{a}$ Emma Gans, ${ }^{a}$ Shuning He, ${ }^{\text {a }}$ Si Chen, ${ }^{a}$ Myunggon Ko, ${ }^{\text {d }}$ You-Yi Kuang, ${ }^{\text {e }}$ Song Yang, ${ }^{f}$ Yi Zhou, ${ }^{f}$ Scott Rodig, ${ }^{\text {h }}$ Leonard I. Zon, ${ }^{f}$ J. Keith Joung, ${ }^{\text {b,c }}$ Anjana Rao, ${ }^{\text {A }}$ A. Thomas Look $^{\mathrm{a}}$

Department of Pediatric Oncology, Dana-Farber Cancer Institute and Harvard Medical School, Boston, Massachusetts, USA; Molecular Pathology Unit, Center for Computational and Integrative Biology, and Center for Cancer Research, Massachusetts General Hospital, Charlestown, Massachusetts, USA ; Department of Pathology, Harvard Medical School, Boston, Massachusetts, USAc; Division of Signaling and Gene Expression, La Jolla Institute for Allergy and Immunology, La Jolla, California, USAd; Heilongjiang River Fisheries Research Institute, Chinese Academy of Fishery Sciences No. 232, Daoli District Harbin, Heilongjiang, People's Republic of Chinae; Division of Hematology/Oncology, Children's Hospital Boston and Dana-Farber Cancer Institute, Boston, Massachusetts, USAf; Department of Hematology, UCL Cancer Institute, University College London, London, United Kingdom'; Brigham and Women's Hospital, Boston, Massachusetts, USA
\end{abstract}

The ten-eleven translocation 2 gene (TET2) encodes a member of the TET family of DNA methylcytosine oxidases that converts 5-methylcytosine $(5 \mathrm{mC})$ to 5 -hydroxymethylcytosine $(5 \mathrm{hmC})$ to initiate the demethylation of DNA within genomic CpG islands. Somatic loss-of-function mutations of TET2 are frequently observed in human myelodysplastic syndrome (MDS), which is a clonal malignancy characterized by dysplastic changes of developing blood cell progenitors, leading to ineffective hematopoiesis. We used genome-editing technology to disrupt the zebrafish Tet 2 catalytic domain. $t e t 2^{m / m}$ (homozygous for the mutation) zebrafish exhibited normal embryonic and larval hematopoiesis but developed progressive clonal myelodysplasia as they aged, culminating in myelodysplastic syndromes (MDS) at 24 months of age, with dysplasia of myeloid progenitor cells and anemia with abnormal circulating erythrocytes. The resultant tet $2^{m / m}$ mutant zebrafish lines show decreased levels of $5 \mathrm{hmC}$ in hematopoietic cells of the kidney marrow but not in other cell types, most likely reflecting the ability of other Tet family members to provide this enzymatic activity in nonhematopoietic tissues but not in hematopoietic cells. tet $2^{\mathrm{m} / \mathrm{m}}$ zebrafish are viable and fertile, providing an ideal model to dissect altered pathways in hematopoietic cells and, for small-molecule screens in embryos, to identify compounds with specific activity against tet 2 mutant cells.

T ET2 belongs to the TET (ten-eleven translocation) family of methylcytosine oxidases, which require 2-oxoglutarate, oxygen, and Fe(II) for their activity. TET2, like TET1 and TET3, modifies the methylation status of the genome, regulating the transcription of specific genes by converting 5 -methylcytosine $(5 \mathrm{mC})$ to 5-hydroxymethylcytosine (5hmC) and then to 5-formylcytosine (5fC) and finally to 5-carboxylcytosine ( $5 \mathrm{caC})$. Each of the last 3 products is recognized and excised by thymine DNA glycosylase (TDG), completing the removal of the 5-methyl group and regenerating unmodified cytosine (1). Hydroxylation of $5 \mathrm{mC}$ by the TET enzymes, returning cytosine to its unmethylated state, has been shown to be crucial to many aspects of embryonic development, including embryonic stem cell (ESC) renewal, epigenetic programming of zygotic cells, and meiosis of primordial germ cells (PGCs) (reviewed in references 2 and 3).

A variety of alterations, including deletions and missense, nonsense, and frameshift mutations, inactivate the TET2 enzyme in different types of human myeloid malignancies, such as myelodysplastic syndromes (MDS) (25 to 35\%) (4-7), myeloproliferative neoplasms (MPN) (2 to 20\%) $(8,9)$, de novo acute myeloid leukemia (AML) (12 to 17\%) (10-14), secondary AML (24 to $32 \%)(11,12)$, and chronic myelomonocytic leukemia (CMML) (50 to 60\%) (5). In these diseases, TET2 gene alterations lead to a marked reduction in global levels of $5 \mathrm{hmC} \mathrm{(15).} \mathrm{TET2} \mathrm{mutations}$ have also been identified in the hematopoietic cells of otherwise healthy adults over 50 years of age who have "clonal skewing" of their bone marrow cells (16), indicating that TET2 mutations may represent one of the first mutations leading to clonal expansion and the eventual development of myeloid malignancies.
The role of TET2 mutations in myeloid malignancies has been studied in a number of mouse models (17-20). The hematopoietic stem cells (HSCs) in these models have low $5 \mathrm{hmC}$ content and exhibit increased self-renewal ability and a competitive advantage over wild-type HSCs for repopulating hematopoietic lineages. Tet 2 knockout mice are viable and fertile and appear to develop normally. However, as they age, Tet2-deficient mice are prone to develop myeloid malignancies, predominantly CMML, with 20 to $30 \%$ developing disease after 8 months of age, clearly suggesting that additional genetic lesions are needed to initiate myeloid malignancy.

Thus, the essential role of TET2 in maintaining the normal growth and development of myeloid lineage cells is evident from both studies in murine models of Tet 2 loss and the demonstration

Received 22 July 2014 Returned for modification 3 September 2014 Accepted 3 December 2014

Accepted manuscript posted online 15 December 2014

Citation Gjini E, Mansour MR, Sander JD, Moritz N, Nguyen AT, Kesarsing M, Gans E, He S, Chen S, Ko M, Kuang Y-Y, Yang S, Zhou Y, Rodig S, Zon LI, Joung JK, Rao A, Look AT. 2015. A zebrafish model of myelodysplastic syndrome produced through tet2 genomic editing. Mol Cell Biol 35:789-804.

doi:10.1128/MCB.00971-14.

Address correspondence to A. Thomas Look, thomas_look@dfci.harvard.edu. Supplemental material for this article may be found at http://dx.doi.org/10.1128 /MCB.00971-14

Copyright $\odot$ 2015, American Society for Microbiology. All Rights Reserved. doi:10.1128/MCB.00971-14 
of TET2 loss-of-function mutations in individuals with "clonal skewing" of hematopoietic cells from the blood and bone marrow. These findings suggest that the clonal dominance by TET2-mutated HSCs may represent a critical precursor event in the development of myeloid cell malignancies. Thus, the specific targeting of TET2 mutant HSCs might provide a means not only to treat patients with existing myeloid malignancies but also to prevent progression to myeloid malignancy in individuals with clonal skewing of hematopoiesis. Meeting this challenge will require animal models conducive to high-throughput analysis of hematopoietic cell phenotypes and to the discovery of genes and signaling pathways that expose targetable vulnerabilities in TET2 mutant cells. The zebrafish has been shown to provide a faithful model of vertebrate hematopoiesis in which both small-molecule and genetic screens have proven particularly advantageous. For example, small-molecule screens conducted in zebrafish embryos have yielded insights directly relevant to pathways regulating both human HSCs and more differentiated hematopoietic cells, leading to the discovery of drugs that augment engraftment, as shown in clinical trials of cord blood cell transplantation in patients (21-30).

Here, we report the use of zinc finger nuclease technology to generate stable zebrafish lines with loss-of-function mutations in the tet 2 gene that truncate the encoded protein and disrupt the catalytic activity of the hydroxylase. Homozygous tet 2 mutant zebrafish are viable and fertile and have undetectable $5 \mathrm{hmC}$ content in blood cells of the kidney marrow but not in other tissues. This suggests that Tet2 is required for methylcytosine dioxygenation in hematopoietic cells but that this function can be supplanted by Tet1 or Tet 3 in other tissues, providing an explanation for the observation that TET2 mutations are found only in hematologic malignancies. Moreover, the tet 2 mutant zebrafish developed myelodysplasia of the kidney marrow at 11 month of age, with a clonal marrow cell population harboring decreased numbers of erythrocytes and increased numbers of myelomonocyte and progenitor cell populations. However, their peripheral blood counts at this age were normal, suggesting that the process had advanced to a stage similar to pre-MDS in patients. By 24 months of age, the tet 2 mutant zebrafish had progressed to full-blown MDS, with a decrease in erythrocytes in the peripheral blood. Thus, the tet $2^{\mathrm{m} / \mathrm{m}}$ (homozygous for the mutation) zebrafish provides a reliable model for studying myeloid malignancies with TET2 loss, with a view to identifying specific small-molecule inhibitors and potential synthetic-lethal genetic interactions.

\section{MATERIALS AND METHODS}

Zebrafish maintenance and genetic manipulation. Wild-type stocks of $\mathrm{AB}$ fish, transgenics, and mutant lines were maintained according to a previously reported protocol (31). Animal handling was approved by the Dana-Farber Institutional Animal Care and Use Committee. Tg(cmybEGFP) and $\operatorname{Tg}(c d 41-E G F P)$ lines are described elsewhere (32, 33). Developmental staging was performed as described previously (34). For genome editing of the tet 2 gene, we utilized protocols similar to those recently described and engineered zinc finger nucleases (ZFNs) made by the context-dependent assembly (CoDA) method $(35,36)$. pCS2-based expression plasmids containing our CoDA ZFNs were linearized downstream of the simian virus 40 (SV40) polyadenylation signal and used as templates for in vitro transcription of ZFN mRNAs (Ambion). One-cell fertilized zebrafish embryos were injected with various amounts of mRNAs encoding ZFNs harboring DD/RR or EL/KK variant FokI nu- clease domains. Site-specific ZFN function was verified by PCR on genomic DNA (gDNA) using tet2-specific primers and then sequencing.

Whole-mount in situ hybridization. Embryos at the desired time points were fixed overnight in $4 \%$ paraformaldehyde (PFA) at $4^{\circ} \mathrm{C}$. Whole-mount in situ hybridization (WISH) was performed as previously described $(31,32)$.

Genotyping. For embryo stages and adult stages, fish were individually genotyped using one forward (5' ATCTCCAAGGTCTTGCAACCTA $3^{\prime}$ ) and one reverse (5'ATACAAGCCCTCATCCACTGAT 3') primer. The forward primer was located in the sixth exon of tet 2 and the reverse primer in the eighth exon. PCR products $668 \mathrm{bp}$ in length were sequenced with the forward primer.

Immunohistochemistry. Embryos were fixed for $1 \mathrm{~h}$ in $4 \%$ paraformaldehyde at room temperature and then washed in phosphate-buffered saline-Tween (PBST) and permeabilized in phosphate-buffered saline (PBS) plus $0.1 \%$ Triton for $30 \mathrm{~min}$ at room temperature. The embryos were blocked in $2 \%$ fetal bovine serum (FBS)-PBST for $1 \mathrm{~h}$ and then incubated in primary antibody overnight at $4^{\circ} \mathrm{C}$. The anti-5hmC (Active Motif) antibody was used at a dilution of 1:100 and anti-enhanced green fluorescent protein (anti-EGFP) at 1:200. For 5hmC detection, an Alexa Fluor 647-goat anti-rabbit secondary antibody $(1: 1,000)$ was used, while for EGFP detection, an Alexa Fluor 488-goat anti-mouse secondary antibody $(1: 1,000)$ was used. Subsequently, embryos were washed in PBST and prepared for imaging.

Paraffin-embedded formaldehyde-fixed sections of adult zebrafish were used for immunohistochemistry using the anti-5hmC (Active Motif; 1:5,000 dilution) primary antibody as described previously (37).

Imaging. Embryos were imaged on a Leica M420 microscope with a Nikon camera and NIS Elements software. For live bright-field images, embryos were treated with $0.4 \%$ tricaine and mounted in $1.5 \%$ methylcellulose. The fixed embryos were mounted in $90 \%$ glycerol. Confocal microscopy images were taken on a Leica SP5X laser scanning confocal microscope, with embryos mounted in $1 \%$ low-melting-point agarose.

Cell suspension preparation and flow cytometry. Wild-type, tet $2^{w t / m}$, and $t e t 2^{m / m}$ fish were anesthetized with $0.02 \%$ tricaine before kidney removal. The kidney was dissected and placed in ice-cold $0.9 \times$ PBS containing $5 \%$ fetal calf serum (FCS). Single-cell suspensions were generated by aspiration, followed by mild teasing of the kidney on a $40-\mu \mathrm{m}$ nylon mesh filter with a pipette tip. Blood cell populations were analyzed on a BD FACSAria with high forward scatter/side scatter (FSC/SSC), as previously described (38). Data analyses were performed using FlowJo software (TreeStar, Ashland, OR). Statistical analysis was done using Prism. Unpaired Student $t$ tests were performed in Prism to determine the $P$ value for each genotype group compared to controls.

Peripheral blood cell counts. Wild-type, tet $2^{w t / m}$, and $t e t 2^{m / m}$ fish were anesthetized with $0.02 \%$ tricaine, and $1 \mu$ l blood was obtained by cardiac puncture. The $1-\mu l$ amount of peripheral blood was diluted in 499 $\mu \mathrm{l}$ of $0.9 \times$ PBS containing $5 \%$ FCS. Ten microliters of heparin sodium (1,000 units $/ \mathrm{ml})$ was added to prevent blood coagulation, and $20 \mu \mathrm{l}$ of Flow-Check fluorospheres ( $10^{6}$ fluorospheres $/ \mathrm{ml}$; Beckman Coulter, Inc.) was added to this solution. The number of cells corresponding to 1,000 counted fluorospheres was obtained using a BD FACSAria with high forward scatter/side scatter, as previously described. Data analyses were performed using FlowJo software (TreeStar, Ashland, OR).

Quantitative-PCR analysis. RNA from sorted cells was extracted with TRIzol reagent (Invitrogen). cDNA was synthesized with Superscript III (Invitrogen). Quantitative PCR (qPCR) was carried out on a ViiA 7 realtime PCR (RT-PCR) system using SYBR green. The fold change was calculated by the $\Delta \Delta C_{T}$ method normalized to $\beta$-actin. The primer sequences are shown in Table 1.

Kidney smears and MGG staining. The kidney was dissected and smeared on glass slides. The slides were fixed and stained with May-Grünwald-Giemsa (MGG) stain (Sigma-Aldrich) according to the manufacturer's instructions and visualized with an Olympus BX51 microscope (Olympus). 
TABLE 1 Primer sequences for RT-PCR

\begin{tabular}{lll}
\hline Zebrafish gene & Primer $^{a}$ & Sequence \\
\hline tet1 & Fw & 5' GATCTGTAGGCTCAGGAGGTGTAT 3' \\
& Rev & 5' GTATGTAATGCGCCTCTTCCTCT 3' \\
tet2 & Fw & 5' CAGTGTATAAGAAAATGGCACCTG 3' \\
& Rev & 5' CTCGCGATTATCCTCTCTTGTTAG 3' \\
tet3 & Fw & 5' CTAGCAGAAACTCCAGAGAAGACC 3' \\
& Rev & 5' GTAACCATGTATGGCTCCATTG 3' \\
3-actin & Fw & 5' TACAATGAGCTCCGTGTTGC 3' \\
& Rev & 5' ACATACAATGGCAGGGGTGTT 3' \\
\hline
\end{tabular}

${ }^{a} \mathrm{Fw}$, forward; Rev, reverse.

Dot blot analysis. Dot blot analysis was performed as previously described (15).

Whole-genome sequencing and analysis. Genomic DNA from the kidney and the fin was prepared using the DNeasy blood and tissue kit (Qiagen). Sequencer-ready DNA fragment libraries were prepared from genomic DNA using PCR-free and Nano kits (Illumina). The sequences were run in a 100-bp paired-end run in the high-capacity run mode using HiSeq 2000 (Illumina).

Before mapping, the raw reads were trimmed and the low-quality bases were removed using the FASTX tool kit (http://hannonlab.cshl.edu /fastx_toolkit/) with quality thresholds at a quality number corresponding to a PHRED score $(Q)$ of $\geq 20$ and a length of $\geq 75$. The trimmed reads were mapped using the BWA MEM algorithm (http://bio-bwa .sourceforge.net/), and duplicated reads were marked using the Picard tool kit (http://sourceforge.net/projects/picard/). The GATK package was used to make single-nucleotide polymorphism (SNP) and insertion-deletion mutation (indel) calls between fin and kidney samples (see the description of GATK best practices [http://www.broadinstitute.org/gatk /guide/best-practices]). The SNPs at locations with more than 20 reads each from kidney and fin samples are listed in Table S1 in the supplemental material.

\section{RESULTS}

Generation of tet 2 mutant zebrafish lines by genome editing. Zinc finger nuclease technology $(35,36)$ was used to induce double-strand DNA breaks within the coding sequences in exon 7 of the tet 2 gene in the zebrafish to produce lines with premature stop codons within the catalytic domain of the protein (Fig. 1A). Single-cell embryos injected with mRNAs encoding the zinc finger FokI fusion proteins targeting the site were grown to maturity and outcrossed to identify F1 progeny in which infidelity in repair by nonhomologous end joining introduced indels at the cleavage site that can disrupt the tet 2 reading frame. We generated two independent tet 2 mutant alleles, encoding Tet $2 \Delta 4$ and Tet $2 \Delta 5$, that possess 4 - and 5-bp deletions, respectively, in exon 7 (Fig. 1B). The Tet $2 \Delta 4$ and Tet $2 \Delta 5$ lines were derived independently from separate injected embryos with genome editing after cleavage with the $\mathrm{Zn}$ finger nucleases. Although the data shown here are from experiments performed using the Tet $2 \Delta 4$ line, we performed each experiment with both the Tet $2 \Delta 4$ and Tet $2 \Delta 5$ lines. Indels introducing premature stop codons within exons 7 and 8 are observed in human patients with myeloid malignancies (39). Thus, our mutant animals are faithful to mutations found in human myeloid malignancies. The 4-bp deletion in Tet $2 \Delta 4$ (ACAT) and the 5-bp deletion in Tet $2 \Delta 5$ (CAAGG) led to stop codons in amino acid 1162 (AA1162) and AA1168, respectively (Fig. 1C), before the third iron-binding site, AA1573, and the 2-oxoglutarate binding site, AA1588, which are found in the double-stranded beta-helix (DSBH) region of the catalytic domain in the Tet 2 protein. These binding sites within the catalytic domain are crucial for the activity of the enzyme in converting $5 \mathrm{mC}$ to $5 \mathrm{hmC}$ (Fig. 1D). There is only one orthologue of TET2 in the zebrafish genome, and alignment of the predicted zebrafish and human proteins showed a high level of conservation for the three iron-binding sites (zebrafish

A

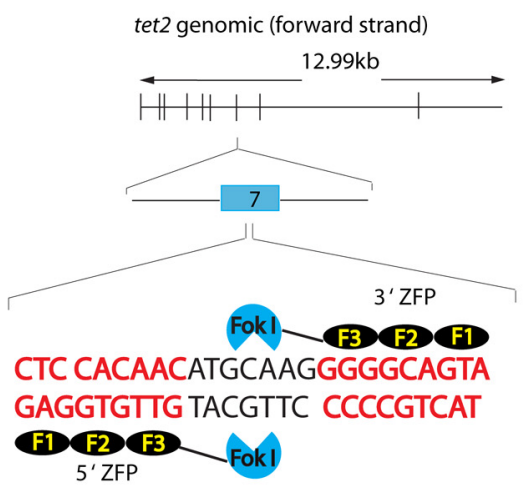

B Tet2 exon 7 ....CATGCTCACAGAGACCTCCACAACATGCAAGGGGGCAGTACTGTG Tet2 $\triangle 4(-4) \quad$....CATGCTCACAGAGACCTCCACA ----GCAAGGGGGCAGTACTGTG Tet2 $\triangle 5(-5) \quad$....CATGCTCACAGAGACCTCCACAACATG -... - - GGGCAGTACTGTG

C tet2 exon 7 VEHENRAPDCRLGLKEGRPFSGVTACLDFCAHAHRDLHNM QGGSTVV tet2 exon $7 \triangle 4$ VEHENRAPDCRLGLKEGRPFSGVTACLDFCAHAHRDLHSK GAVLWSARX tet2 exon $7 \Delta 5$ VEHENRAPDCRLGLKEGRPFSGVTACLDFCAHAHRDLHNM GQYCGLHANKRGX

D H Tet2 (2002 a.a.)
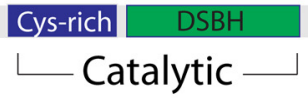

Zf Tet2 (1715 a.a.)
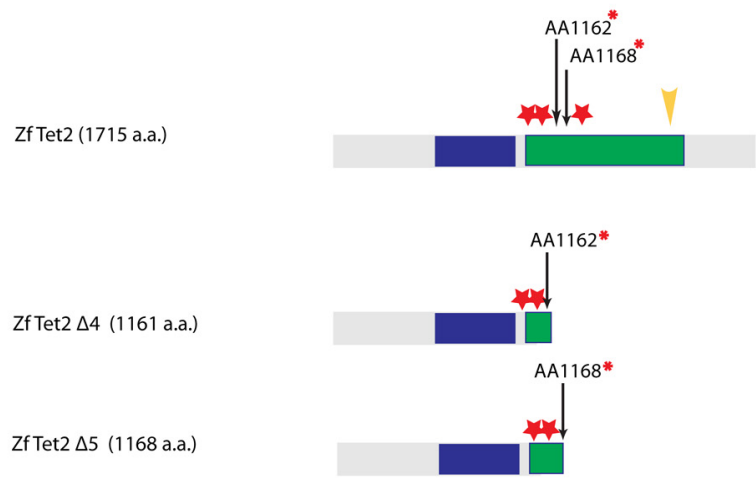

\footnotetext{
$\checkmark$ iron- binding site

2-oxoglutarate binding sit
}

FIG 1 Genome editing using targeted Fok1 cleavage to generate null alleles of the zebrafish tet2 gene. (A) Site-specific targeting for ZFN-directed Fok1 cleavage within exon 7 of the zebrafish tet2 gene. (B) Alignments of nucleotide sequences from wild-type and mutant tet 2 alleles in the Tet $2 \Delta 4$ and Tet $2 \Delta 5$ zebrafish lines. ZFN binding sites appear in red. The dashes in the DNA sequence represent the nucleotides that are deleted during repair of Fok1-induced double-strand breaks. (C) Targeted Fok1-induced mutagenic lesions in tet 2 produce frameshift mutations that lead to truncated protein products following short regions of novel amino acids, which are indicated in green. (D) The truncated protein products predicted by the mutant tet 2 alleles encoding Tet $2 \Delta 4$ and Tet $2 \Delta 5$ lack most of the Tet 2 catalytic domain. a.a., amino acids. 


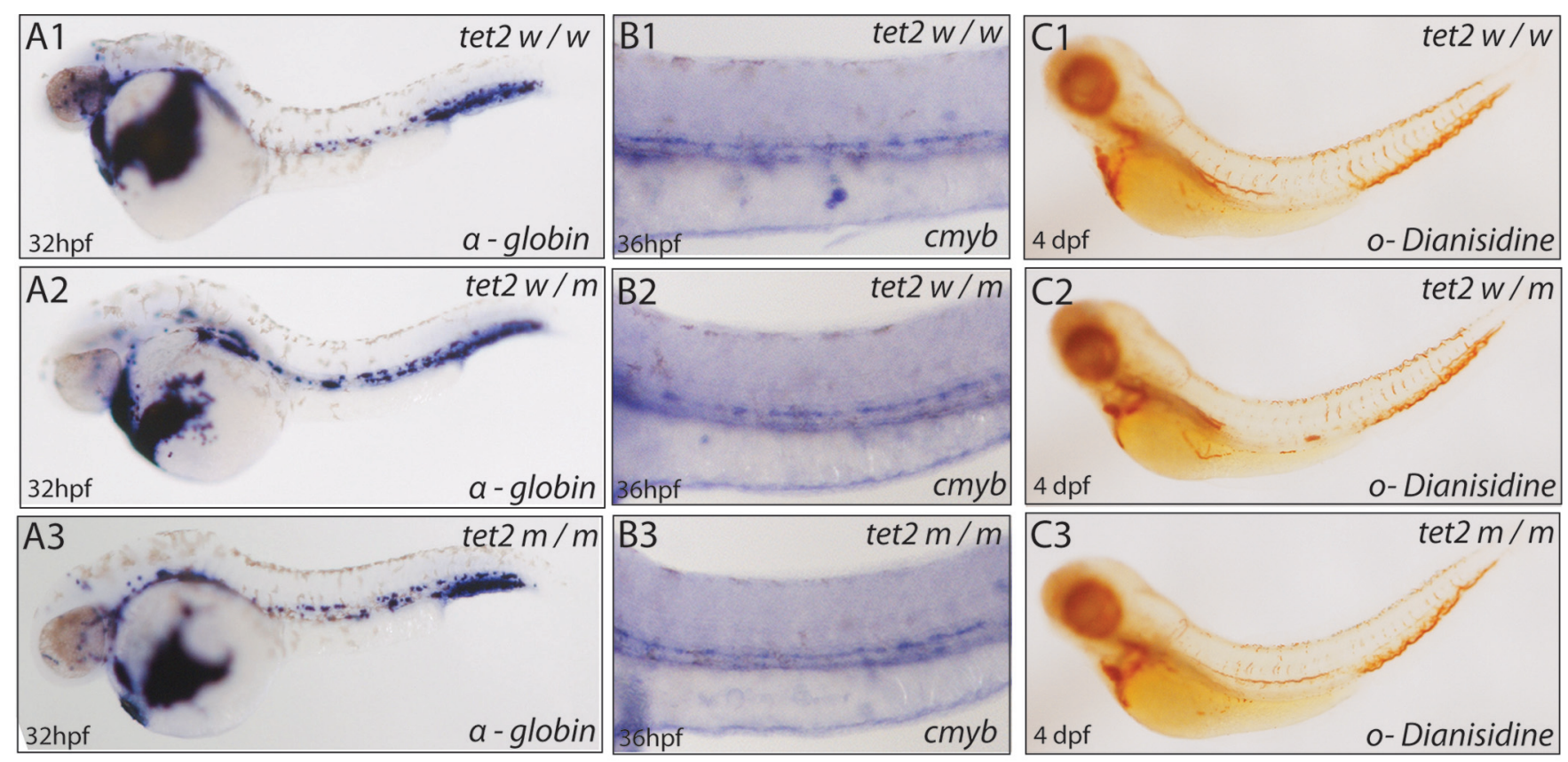

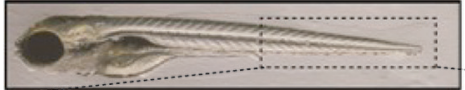
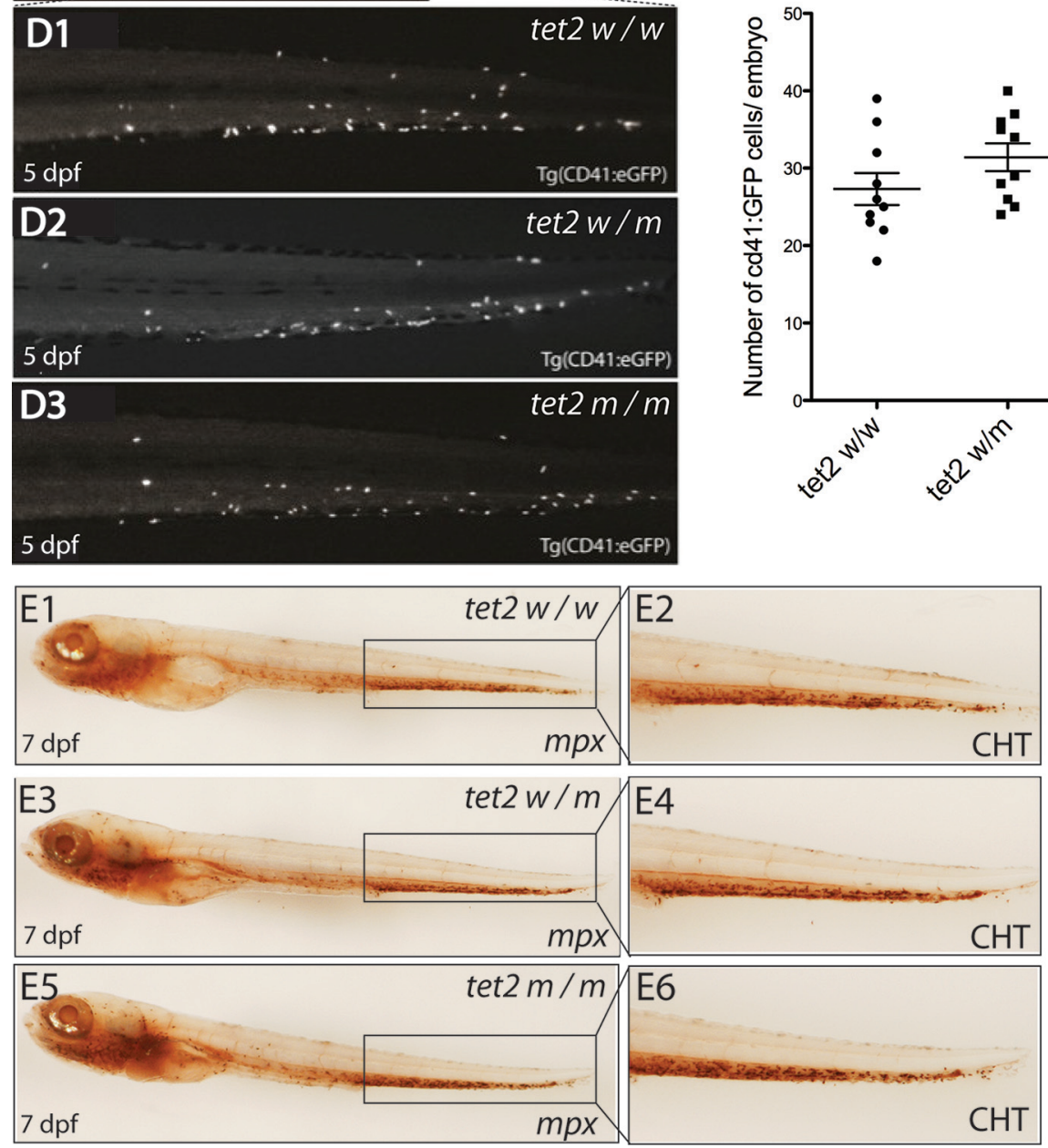

D4
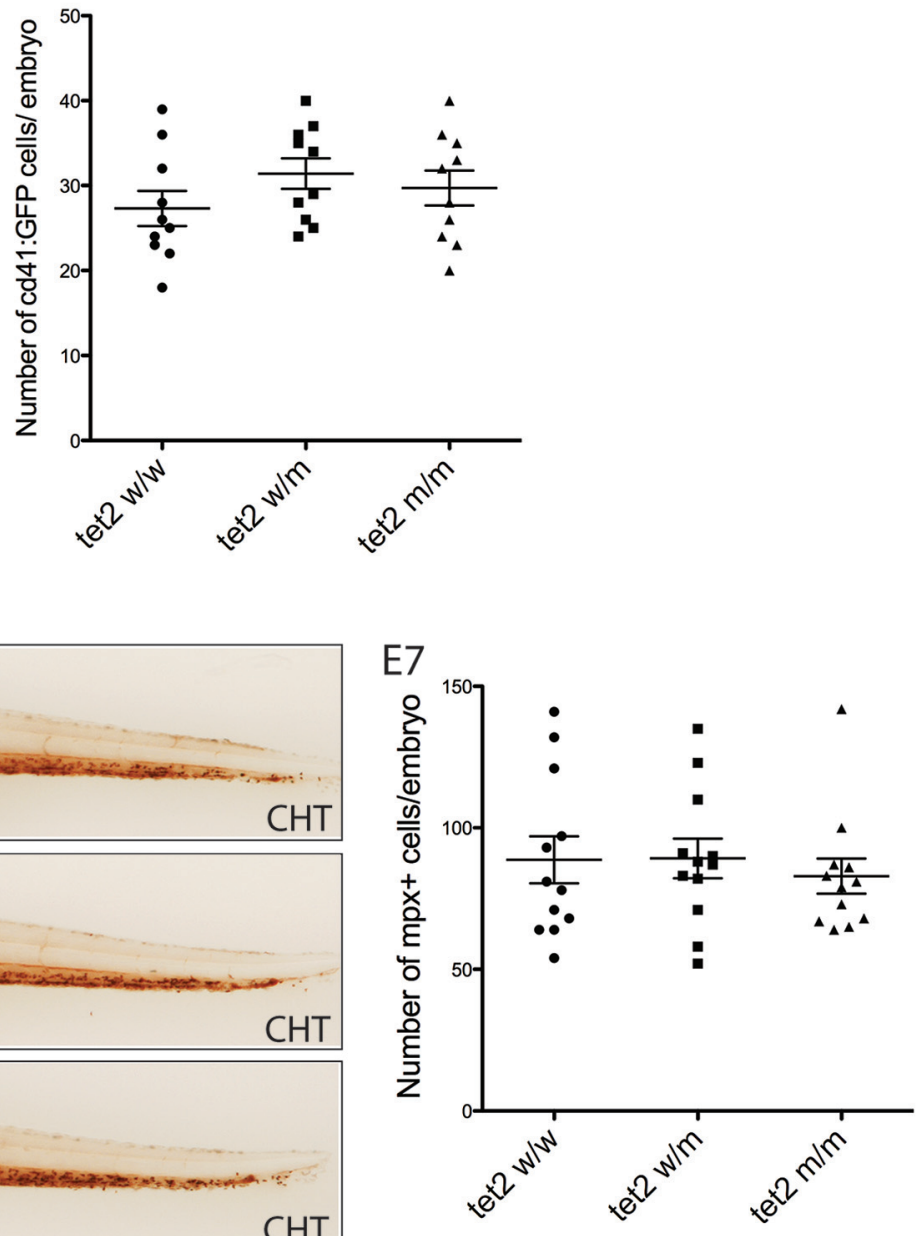
AA1126, AA1129, and AA1573; human AA1382, AA1384, and AA1881) and the 2-oxoglutarate binding site (zebrafish AA1588; human AA1896) (see Fig. S1 in the supplemental material). We observed the same results in studies with each of the independently derived lines. Quantitative-RT-PCR (qRT-PCR) analysis of the tet 2 RNA sequences in heterozygous fish showed that RNAs containing the mutations were expressed and apparently were not subject to nonsense-mediated decay, even though they encode a truncated protein (see Fig. S2A in the supplemental material). The two heterozygous tet 2 mutant lines, Tet $2 \Delta 4$ and Tet $2 \Delta 5$, were inbred to generate homozygous $t e 2^{\mathrm{m} / m}$ zebrafish lines, which were viable and fertile and lacked any detectable developmental or morphological defects. Thus, we conclude that tet 2 loss is dispensable for the development and viability of the zebrafish.

tet $2^{m / m}$ zebrafish embryos undergo normal hematopoiesis. To assess the effect of tet2 loss on embryonic hematopoiesis, we performed WISH on the progeny of a cross of two tet $2^{\text {wt } / m}$ adult fish expressing $\alpha$-globin (Fig. 2A1 to A3) and $c m y b$ (Fig. 2B1 to B3) at 32 and $36 \mathrm{~h}$ postfertilization (p.f.). Analysis of RNA expression of the two genes showed no differences in cells expressing $\alpha$-globin (erythroid cells) or $c m y b$ (hematopoietic stem cells) in tet $2^{w t / w t}$ (homozygous wild type), tet $2^{w t / m}$, and $t e t 2^{m / m}$ embryos, in contrast to recent findings by $\mathrm{Ge}$ at al. using tet 2 morpholinos (40). Moreover, cells expressing mpo (myeloid cells) were not impaired in $t e t 2^{m / m}$ zebrafish embryos in comparison with those in wildtype and heterozygous embryos (see Fig. S2B in the supplemental material). Whole-mount $o$-dianisidine staining for heme was also unchanged in 4-day-old tet $2^{w t / w t}$, tet $2^{w t / m}$, and $t e t 2^{m / m}$ embryos, indicating normal levels of hemoglobin-containing erythrocytes in the circulation (Fig. 2C1 to C3). Analysis of green fluorescent protein-positive $\left(\mathrm{GFP}^{+}\right)$platelet progenitors in the caudal hematopoietic tissue (CHT) of wild-type, heterozygous, and $t e t 2^{m / m}$ fish at 5 days of age was performed by cell counts in the $\operatorname{Tg}(c d 41$ GFP) background (Fig. 2D1 to D3). We did not observe a significant difference in the number of cd $41^{+}$cells in tet $2^{w t / m}$ and tet $2^{\mathrm{m} / \mathrm{m}}$ embryos compared with tet $2^{w t / w t}$ fish embryos (Fig. 2D4). Similarly, the numbers of myeloperoxidase-positive $\left(\mathrm{mpx}^{+}\right)$cells in the CHT regions of 7-day-old tet $2^{w t / w t}$, tet $2^{w t / m}$, and $t e t 2^{m / m}$ embryos were assessed by histochemistry (Fig. 2E1 to E6). This analysis did not reveal any differences between the three groups (Fig. 2E7). To investigate Tet 2 loss in zebrafish hematopoietic stem and progenitor cells (HSPCs), we determined the relative numbers of $\mathrm{cmyb}^{+}$cells in 5-day-old tet $2^{w t / w t}$, tet $2^{w t / m}$, and $t e t 2^{\mathrm{m} / m}$ zebrafish embryos using the $\mathrm{Tg}(\mathrm{cmyb}-\mathrm{GFP})$ zebrafish transgenic reporter line (32) (see Fig. S2C in the supplemental material). We did not observe a difference in the relative numbers of cmyb-EGFP ${ }^{+}$ HSPCs per embryo in $t e t 2^{w t / w t}$, tet $2^{w t / m}$, and $t e t 2^{m / m}$ embryos (see Fig. S2D in the supplemental material). These results show that loss of Tet 2 function does not detectably impair embryonic or early definitive hematopoiesis.
Analysis of $5 \mathrm{hmC}$ expression in zebrafish embryonic hematopoietic stem cells. To investigate Tet2 activity in zebrafish hematopoietic stem cells budding from the ventral wall dorsal aorta at 36 h p.f., we used the $\mathrm{Tg}(\mathrm{cmyb}-\mathrm{GFP})$ zebrafish transgenic reporter line and performed double labeling for GFP and $5 \mathrm{hmC}$ (36). Interestingly, wild-type zebrafish cmyb-GFP-positive HSPCs did not express $5 \mathrm{hmC}$ at this stage of zebrafish hematopoiesis (Fig. 3A2 to A4, white arrows) in the aorta-gonad-mesonephros (AGM) region (Fig. 3A1), but 5 hmC expression was apparent in cmyb-negative cells in the intermediate cell mass (ICM) region of these embryos (yellow arrows). In the cmyb-GFP-positive background, tet $2^{m / m}$ embryos were indistinguishable from wild-type embryos, including the finding that cmyb-GFP-positive tet $2^{m / m}$ HSPCs did not express $5 \mathrm{hmC}$ (Fig. 3A5 to A7).

At 48 h p.f. in the $\mathrm{Tg}(\mathrm{cmyb}-\mathrm{GFP})$ background, the $5 \mathrm{hmC}$ expression in $t e t 2^{w t / w t}$ embryos colocalized with GFP expression in approximately 10 to $15 \%$ of the cells expressing cmyb in the CHT (Fig. 3B1 to B4). Thus, although $5 \mathrm{hmC}$ expression is not present when HSPCs bud from the dorsal aorta, $5 \mathrm{mC}$ modification into $5 \mathrm{hmC}$ is initiated when the HSPCs populate the CHT region. tet $2^{m / m}$ embryos at $48 \mathrm{~h}$ were indistinguishable from tet $2^{w t / w t} \mathrm{em}$ bryos, with $5 \mathrm{mC}$ modification progressing to $5 \mathrm{hmC}$ in HSPCs at this stage of development, despite the absence of functional Tet2 (Fig. 3B5 to B7).

tet 2 loss in zebrafish leads to decreased $5 \mathrm{hmClevels} \mathrm{in} \mathrm{kidney}$ marrow blood cells. To investigate whether tet 2 loss results in decreased levels or loss of $5 \mathrm{hmC}$ in the nuclear DNA of cells in the tissues of adult zebrafish, we performed immunohistochemistry on tissue sections of 4-month-old $\operatorname{tet} 2^{w t / w t}$, tet $2^{w t / m}$, and $\operatorname{tet} 2^{m / m}$ fish using an anti-5hmc antibody (Fig. 4). Interestingly, the 5hmC modification was undetectable in most of the blood cells of the kidney marrow of the tet $2^{\mathrm{m} / \mathrm{m}}$ fish (Fig. 4A3) and markedly different from the $5 \mathrm{hmC}$ expression in the tet $2^{w t / w t}$ zebrafish kidney marrow (Fig. 4A1). Kidney tubule cells in the same fields showed high levels of $5 \mathrm{hmC}$ staining in tet $2^{\mathrm{m} / \mathrm{m}}$ fish (Fig. 4A3), providing an internal nonhematopoietic control cell population for the analysis. Similarly, $5 \mathrm{hmC}$ modification was readily detected in all the cellular nuclei of other organs, such as brain (Fig. 4B1 and B3), intestine (Fig. 3C1 and C3), and muscle (Fig. 3D1 and D3), in both genotypes. In $t e t 2^{w t / m}$ fish, $5 \mathrm{hmC}$ modification was reduced in the kidney marrow compared with the $5 \mathrm{hmC}$ expression in the tet $2^{w t / w t}$ zebrafish kidney marrow, but in a more patchy and less striking pattern than the $5 \mathrm{hmC}$ expression in the whole kidney marrow of the $t e t 2^{m / m}$ zebrafish. Similarly, $5 \mathrm{hmC}$ was detected in all the cellular nuclei of other organs, such as brain, intestine, and muscle (Fig. 4B2, C2, and D2). These results indicate that tet2 loss prevents $5 \mathrm{hmC}$ modification in hematopoietic cells of the kidney marrow by 4 months of age but not in the nuclei of renal tubule cells or the cells of other tissues and organs. Thus, wild-type Tet1 and Tet 3 appear to be able to perform this modification in most

FIG 2 tet2 loss does not alter $\alpha$-globin-expressing erythroid cells or cmyb-positive HPSCs during embryogenesis. (A1 to B3) In situ hybridization for $\alpha$ - $g$ lobin (A1 toA3) at 32 h p.f. and $c m y b$ (B1 to B3) at 36 h p.f. showed no differences in erythroid cells expressing $\alpha$-globin or HSPCs expressing $c m y b$ in $t e t 2^{w t / w t}$, tet $2^{w t / m}$, and tet $2^{m / m}$ zebrafish embryos. (C1 to C3) o-Dianisidine staining for hemoglobin on 4-day-old tet $2^{w t / w t}$, tet $2^{w t / m}$, and tet $2^{m / m}$ embryos showed no differences in circulating erythrocytes. (D1 to D3) Anti-GFP whole-mount immunostaining of the body region (CHT, magnified from the boxed area in the image at the top) of $t e t 2^{w t / w t}, t e t 2^{w t / m}$, and tet $2^{m / m}$ embryos at 5 days p.f. in the $\mathrm{Tg}(c d 41-E G F P)$ background. (D4) Scatter plot showing the number of cd41-GFP ${ }^{+}$cells per embryo, counted in the CHTs of 5-day-p.f. tet $2^{w t / w t}(n=10), \operatorname{tet} 2^{w t / m}(n=10)$, and $t e t 2^{m / m}(n=10)$ fish. Statistical analysis was performed using the unpaired Student $t$ test. The long horizontal lines denote the mean values. The short horizontal lines above and below the means represent the error bars. (E1 to E6) Whole-mount myeloperoxidase staining of 7-day-old tet $2^{w t / w t}$, $t e t 2^{w t / m}$, and $t e t 2^{m / m}$ embryos. (E2, E4, and E6) Mpx-expressing cells were counted in the CHT regions of the embryos. (E7) Scatter plot quantifying the $m p x^{+}$cells per embryo. The long horizontal lines denote the mean values. Statistical analysis was performed using an unpaired Student $t$ test. 

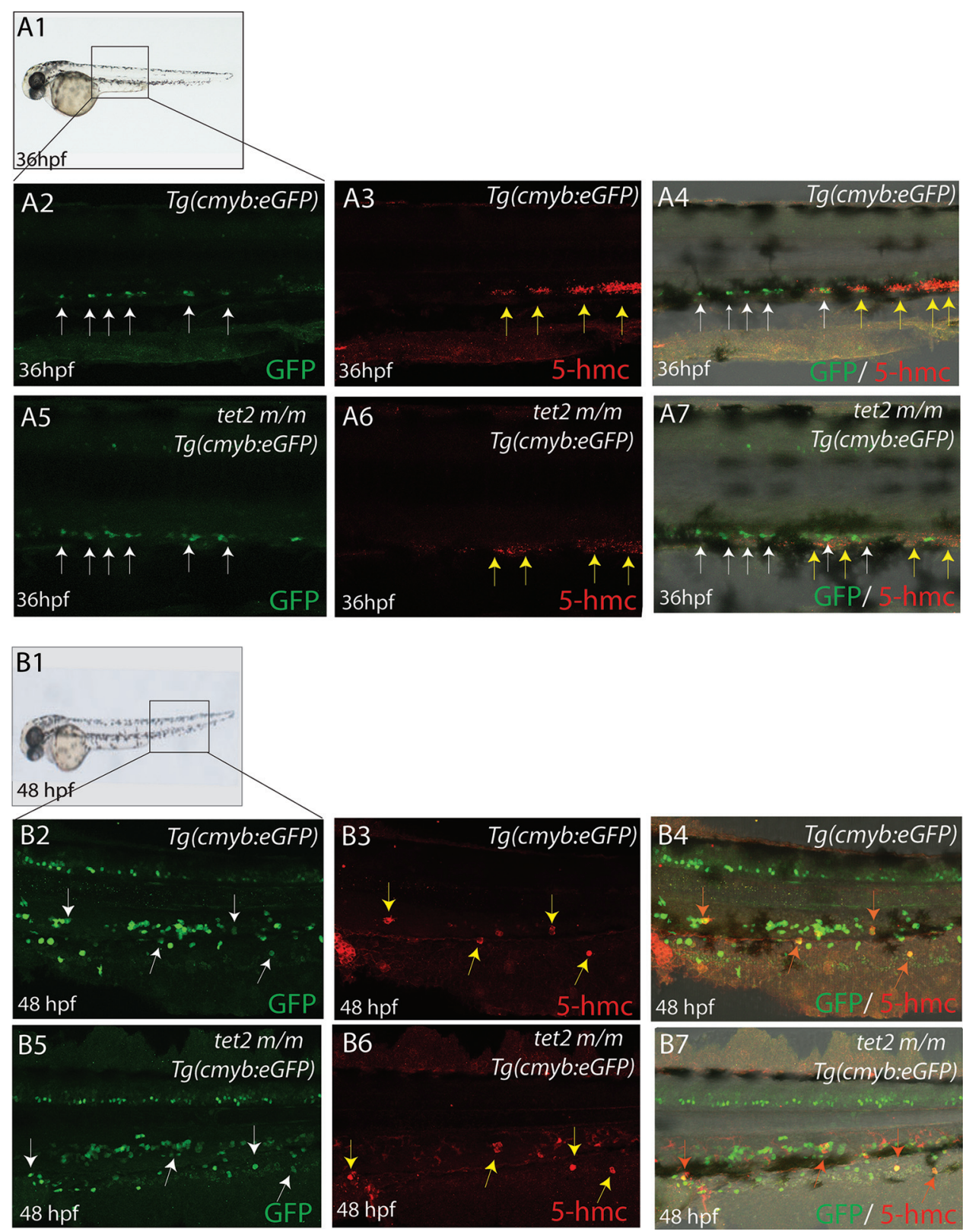

FIG 3 Analysis of $5 \mathrm{hmC}$ expression in zebrafish embryonic hematopoietic stem cells. (A1 to A7) Whole-mount immunohistochemistry for $5 \mathrm{hmC}$ expression on 36-h p.f. wild-type (A2 to A4) and tet $2^{\mathrm{m} / \mathrm{m}}$ (A5 to A7) embryos showed no $5 \mathrm{hmC}$ expression (red signal) in hematopoietic stem cells expressing $\mathrm{cmyb}$ (green signal and white arrows). $5 \mathrm{hmC}$ is expressed in other cell types (red signal and yellow arrows) in the ICM. (A2 and A5) Single-scan imaging for GFP (green signal). (A3 and A6) 5hmC (red signal). (A4 and A7) merged GFP (green signal)-5hmC (red signal). (B1 to B7) Whole-mount immunohistochemistry for 5hmC expression on 48-h p.f. wild-type (B2 to B4) and tet $2^{m / m}$ (B5 to B7) embryos showed $5 \mathrm{hmC}$ expression (red signal) in a subset of cells expressing cmyb in the caudal hematopoietic tissue (green signal and white arrows). (B2 to B7) Single-scan imaging for GFP (green signal) (B2 and B5), 5hmC (red signal) (B3 and B6), and merged GFP (green signal)-5hmC (red signal) (B4 and B7). White arrows, GFP-positive cells; yellow arrows, 5hmC-positive cells; orange arrows, GFP-5hmCpositive cells.

tissues of adult zebrafish when Tet2 function is lost, but not in hematopoietic cells.

To investigate the levels of expression of each tet family member in hematopoietic cells, we sorted zebrafish kidney marrow cells into four subpopulations: (i) erythrocytes, (ii) lymphocytes, (iii) progenitor cells, and (iv) myelomonocytes (Fig. 5). Analysis of wild-type cells showed that each of the tet family members was expressed in all four subpopulations. tet 1 was expressed at higher levels than tet 2 and tet 3 in each cell population except progenitor cells, which expressed equal levels of tet 1 and tet2. Interestingly, in the $t e t 2^{\mathrm{m} / \mathrm{m}}$ animals, the levels of tet 1 , tet 2 , and tet 3 expression were dramatically upregulated in each subpopulation except the myelomonocytes. This suggests the TET2 protein normally mediates a feedback loop regulating transcription of both itself and the other TET family members. Thus, the nonredundancy of Tet 1 and Tet3 in hematopoietic cells is not due to a lack of mRNA expres- 

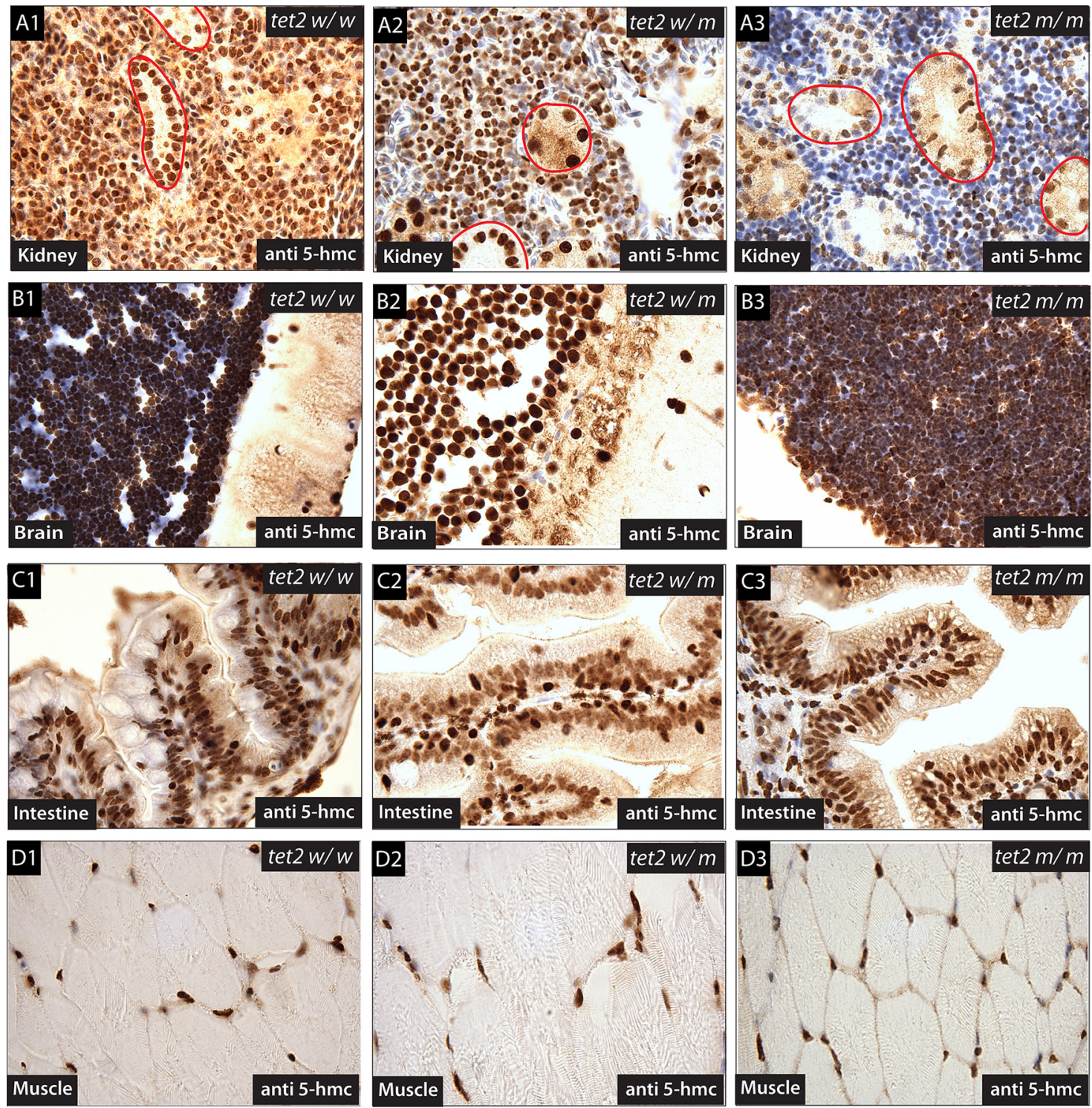

FIG 4 tet 2 loss leads to reduced $5 \mathrm{hmC}$ expression in the kidney marrow in tet $2^{\mathrm{m} / \mathrm{m}}$ adult fish. (A1 to A3) Immunohistochemistry for $5 \mathrm{hmC}$ expression on paraffin sections from adult fish shows loss of $5 \mathrm{hmC}$ expression in the blood cell progenitors of the kidney marrow in the tet $2^{\mathrm{m} / \mathrm{m}}(\mathrm{A} 3)$ not the tet $2^{w t / w t}$ fish. However, the renal glomerular cells (red outlines) in the same field of tet $2^{\mathrm{m} / \mathrm{m}}$ adult fish express $5 \mathrm{hmC}$. tet 2 loss does not affect $5 \mathrm{hmC}$ expression levels in cell nuclei in brain (B1 to $\mathrm{B} 3$ ), intestine (C1 to $\mathrm{C} 3$ ), and muscle (D1 to D3).

sion but is more likely related to lack of functional activity of Tet1 and Tet 2 proteins through mechanisms that are not yet defined. In this regard, it is intriguing that a tumor suppressor role for tet 2 loss by somatic mutation has been found in hematopoietic malignancies only among human cancers $(4,18,41)$, possibly because only hematopoietic cells depend exclusively on Tet 2 to mediate the $5 \mathrm{hmC}$ modification. In mice, the expression levels of individual Tet genes do not always correlate with the degree of their contribution to $5 \mathrm{hmC}$ generation $(42,43)$, and apparently, the same as-yet-unexplained tissue specificity among Tet family members is found in zebrafish tissues.

To confirm the immunohistochemical evidence of $5 \mathrm{hmC}$ loss in the kidney marrow population, we performed a dot blot assay using anti-cytosine 5-methylene sulfonate (anti-CMS) on gDNA isolated from whole kidneys from wild-type and homozygous tet 2 fish. $5 \mathrm{hmC}$ was converted into CMS by bisulfite treatment (17). We also used gDNA isolated from brains from both genetic subgroups. The results obtained by the dot blot assay confirmed that CMS levels did not change in the tet $2^{\mathrm{m} / \mathrm{m}}$ zebrafish brain in comparison with wild-type gDNA isolated from the brain. The CMS levels were decreased in gDNA isolated from tet $2^{\mathrm{m} / \mathrm{m}}$ kidneys compared with CMS levels in the gDNA isolated from tet $2^{w t / w t}$ kidneys (see Fig. S3 in the supplemental material).

Zebrafish homozygous for mutant tet2 develop premyelodysplasia at 11 months of age. FSC/SSC flow cytometry was performed on whole-kidney marrow from tet $2^{\mathrm{m} / \mathrm{m}}$ zebrafish and their siblings. The relative percentages of four different populations (erythrocytes, myelomonocytes, lymphocytes, and progenitor cells) were determined individually in each fish ( $n=10$ per group) at the ages of 4, 6, 8, and 11 months. At 4 and 6 months, the 

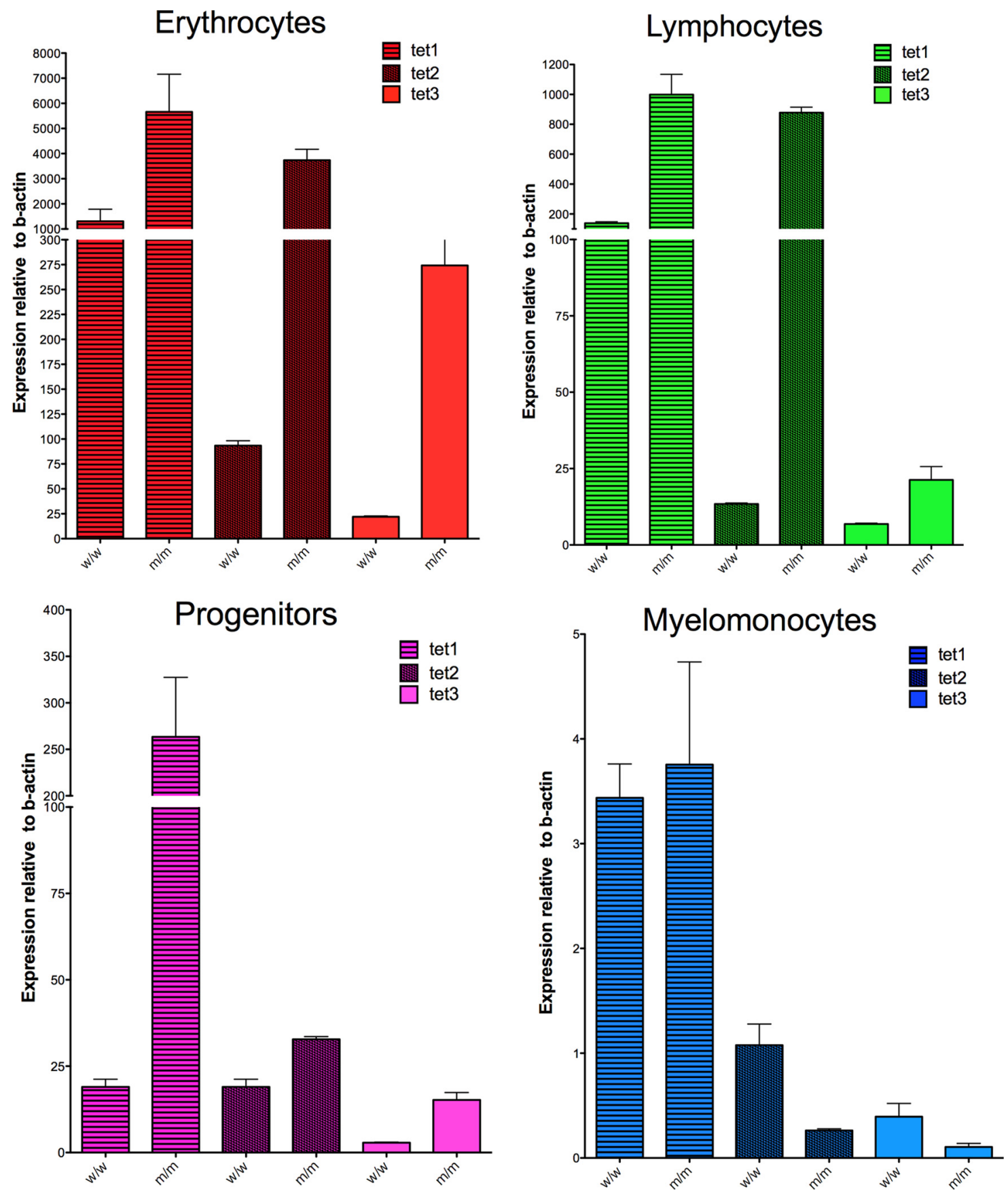

FIG 5 Analysis of tet1, tet2, and tet 3 expression in different blood cell types. qRT-PCR in cDNA from the erythrocytes, lymphocytes, progenitor cells, and myelomonocytes isolated from the kidney marrow was performed to examine the expression of each tet family member in tet $2^{w t / w t}$, tet $2^{w t / m}$, and $t e t 2^{m / m}$ adult zebrafish. The expression levels are shown relative to $\beta$-actin. For this experiment, kidney marrow from 9 tet $2^{w t / w t}$, tet $2^{w t / m}$, and $t e t 2^{m / m}$ adult zebrafish was drawn in 3 groups, each consisting of 3 animals. The bars represent the averages of triplicate runs, and the error bars represent standard errors of the mean (SEM).

percentages of erythrocyte, myelomonocyte, progenitor cell, and lymphocyte populations in the kidneys of the wild-type, heterozygous, and homozygous fish were similar (see Fig. S4A and B in the supplemental material). However, at 8 months of age, there was a clear decrease in the erythrocyte population and an increase in progenitor cells in tet $2^{m / m}$ compared with wild-type fish (see Fig. $\mathrm{S} 4 \mathrm{C}$ in the supplemental material).

Analysis of the different cell populations from the whole-kidney marrow of 11-month-old tet $2^{m / m}$ fish and their siblings, using FSC/ SSC, revealed a decreased number of erythrocytes and expanded numbers of myeloid and progenitor cells in the kidney marrow of tet $2^{m / m}$ compared to wild-type fish (Fig. 6). Eleven-month-old heterozygous tet $2^{w t / m}$ fish showed a significant decrease in the erythrocyte population and a significant increase in the myelomonocyte population in the kidney marrow, but there was no change in the progenitor cell populations of these animals (Fig. 6). 


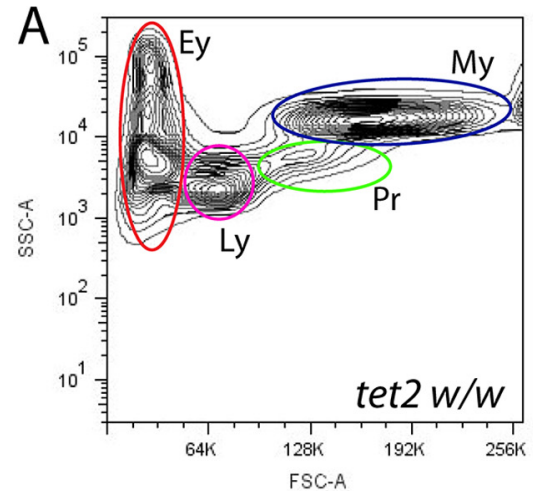

B

Erythrocytes

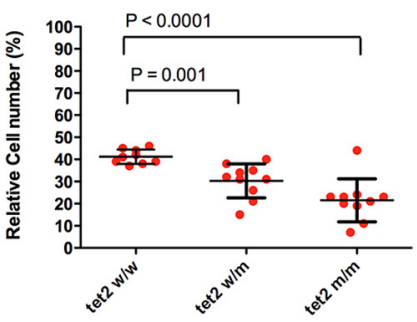

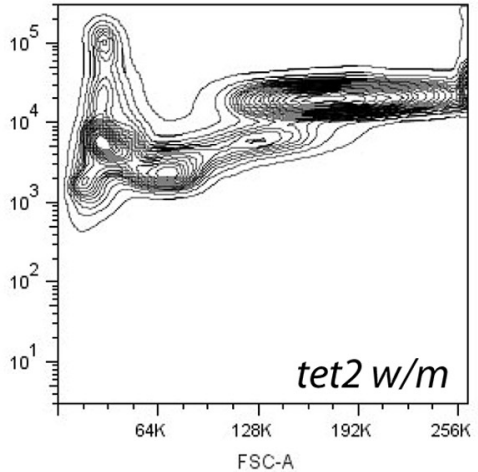

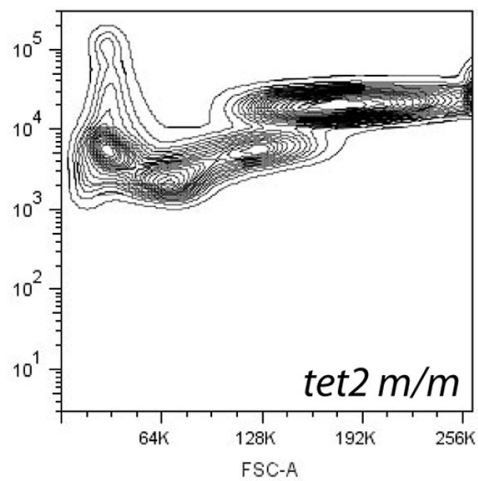

Lymphocytes
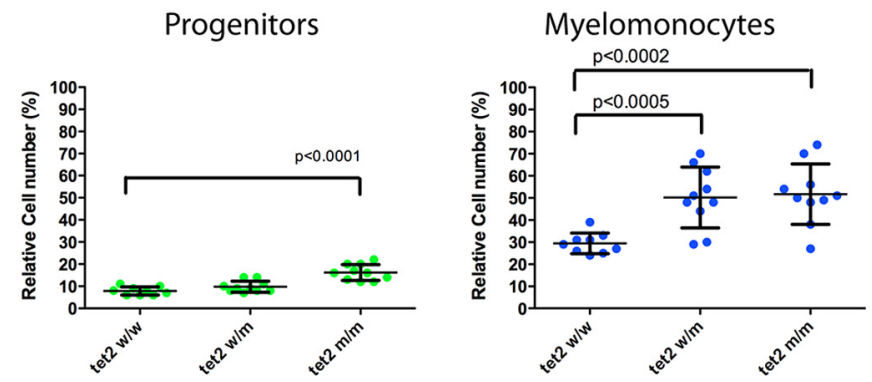

FIG 6 tet $2^{m / m}$ zebrafish develop premyelodysplasia at 11 months of age. (A) Forward versus side scatter analysis plots for kidney marrow cell populations in 11-month-old tet $2^{w t / w t}$, tet $2^{w t / m}$, and $t e t 2^{m / m}$ fish. (B) Analysis of the kidney marrow cell populations of 11 -month-old fish with loss of tet2 showing a significant decrease in erythrocytes and a significant increase in the myelomonocyte population in $t e t 2^{w t / m}$ and tet $2^{m / m}$ fish compared with $t e t 2^{w t / w t}$ fish. A significant increase in the progenitor cell population is observed only in the tet $2^{m / m}$ fish. Ey, erythrocytes; Ly, lymphocytes; Pr, progenitor cells; My, myelomonocytes.

MGG staining of the kidney marrow smears from $t e t 2^{w t / w t}$, tet $2^{w t / m}$, and tet $2^{m / m}$ fish at 11 months of age revealed differences in the morphology of the erythrocyte population and the appearance of dysplastic cells of the myeloid lineage in a subset of heterozygous fish (Fig. 7B1 to B3) and in all homozygous fish (Fig. $7 \mathrm{C} 1$ to C3). The erythrocytes in a subset of heterozygous fish (6 of 11 ) and in all 10 of the tet $2^{\mathrm{m} / \mathrm{m}}$ fish showed deep basophilic cytoplasm compared to the light-pink coloration of erythrocytes in the tet $2^{w t / w t}$ fish (Fig. 7A1 to A3). Analysis of total RNA amounts from 300,000 red blood cells sorted from the kidney marrow of tet $2^{w t / w t}$ and $t e t 2^{\mathrm{m} / \mathrm{m}}$ adult fish showed a 1.5- to 1.8-fold increase in rRNA concentrations in red blood cells with Tet2 loss, potentially explaining the dark basophilic cytoplasm observed in $t e t 2^{w t / m}$ and tet $2^{m / m}$ red blood cells (see Fig. S5 in the supplemental material).

Analysis of the peripheral blood showed that the total blood cell counts of 11-month-old tet $2^{m / m}$ fish were similar to those in tet $2^{w t / m}$ and $t e t 2^{w t / w t}$ fish (Fig. 8A and B). In addition, profiling of the peripheral blood cells by FSC/SSC analysis showed no changes in the different populations of the blood cells in the tet $2^{w t / w t}$, tet $2^{w t / m}$, and $t e t 2^{m / m}$ adult fish (Fig. 8C). These data indicate that loss of tet 2 in zebrafish leads to the development of myelodysplasia of the kidney marrow cells, or what might be called preMDS, since the blood counts are still compensated for to normal at this age.

Assessment of clonality in zebrafish premyelodysplasia. To assess the clonal evolution of hematopoietic cells in the kidney marrow of the tet $2^{\mathrm{m} / \mathrm{m}}$ adult fish, we performed whole-genome sequencing of genomic DNA isolated from the kidney marrow and genomic DNA isolated from the fin of an 11-month-old zebrafish whose kidney marrow smears showed a high percentage of dysplastic myeloid cells. Our data, summarized in Table S1 in the supplemental material, show that the genomic DNA kidney marrow contains new somatically acquired point mutations and indels compared with the genomic DNA sequence obtained from the fin. These mutations do not affect coding sequences and thus do not likely represent drivers of the expansion of myeloid progenitor cells and the myelodysplastic phenotype observed at 11 months of age. Rather, they likely reflect passenger alterations that become apparent only after clonal expansion of tet 2 mutant hematopoietic cells.

Zebrafish homozygous for mutant tet 2 develop MDS at 24 months of age. Flow cytometry analysis of the different cell populations from the whole-kidney marrow of 24-month-old $t e t 2^{\mathrm{m} / \mathrm{m}}$ fish and their siblings revealed a decreased percentage of erythrocytes and increased percentages of myeloid and progenitor cells in the kidney marrow of $t e t 2^{m / m}$ compared to wild-type fish (Fig. 9A). Twenty-four-month-old heterozygous tet $2^{\text {wt } / m}$ fish showed a significant decrease in the erythrocyte population and a significant increase in the myelomonocyte population in the kidney marrow, but there was no change in the progenitor cell populations of these animals (Fig. 9A). Aberrant morphology of the erythrocyte population and the appearance of dysplastic cells of the myeloid lineage, similar to those observed at 11 months of age (Fig. 7), were present in $t e t 2^{w t / m}$ (6 out of 8 ) and tet $2^{\mathrm{m} / m}$ (12 out of 12) fish but not in the tet $2^{w t / w t}$ fish (12 out of 12) (Fig. 9B to D). Analysis of the peripheral blood showed a decrease in the absolute number of erythrocytes in the peripheral blood in the tet $2^{m / m}$ adult fish compared with $t e t 2^{w t / w t}$ and tet $2^{w t / m}$ fish (Fig. 10A). The presence of anemia, together with the dysplastic changes in the kidney marrow progenitor cells, indicates progression to MDS in the tet $2^{\mathrm{m} / \mathrm{m}}$ 

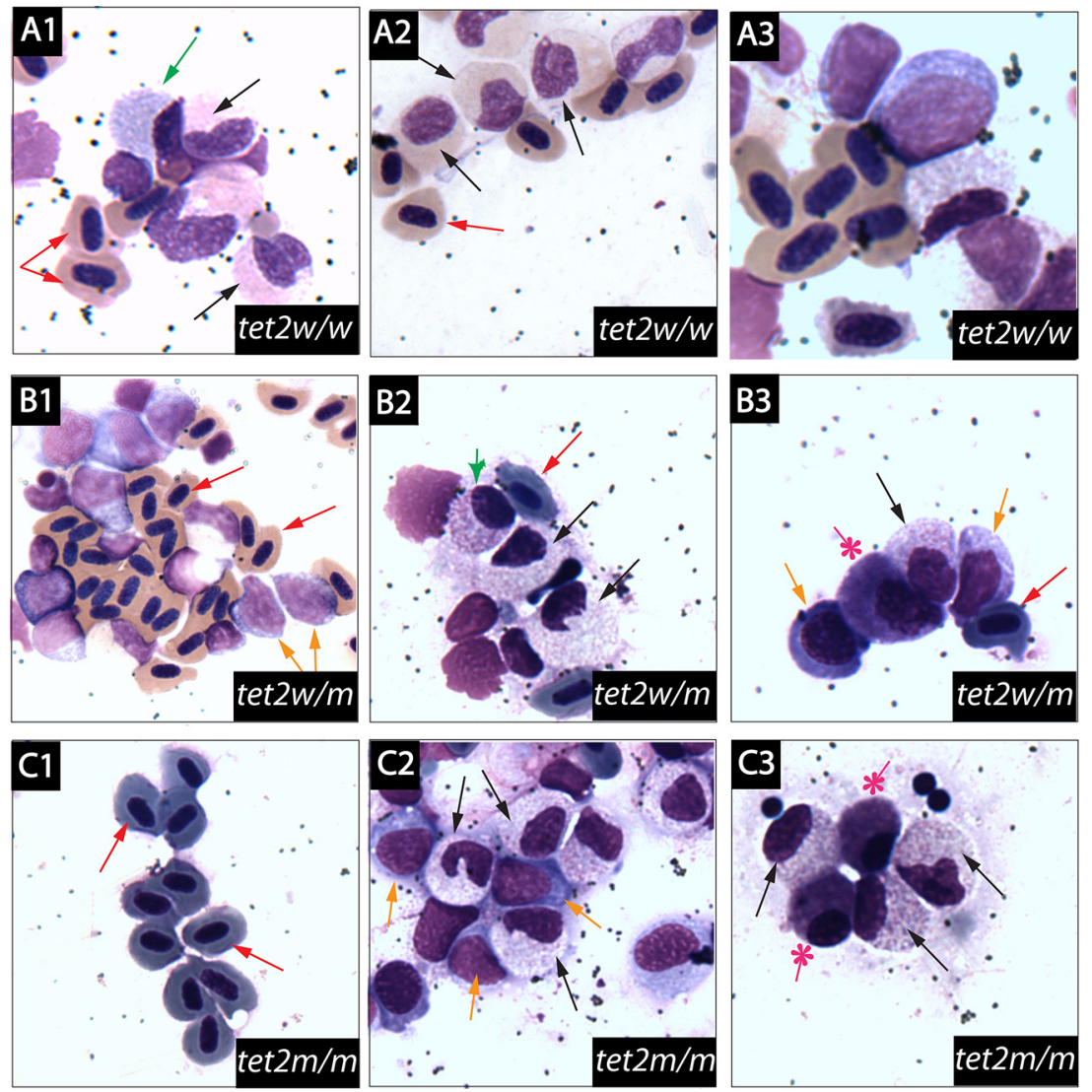

FIG 7 Morphological analysis of blood cell types in the kidneys of $t e t 2^{w t / w t}$, tet $2^{w t / m}$, and $t e t 2^{m / m} 11$-month-old fish. Analysis of kidney smears revealed the presence of all hematopoietic lineages in $t e t 2^{w t / w t}$, tet $2^{w t / m}$, and $t e t 2^{\mathrm{m} / m} 11$-month-old fish. (A1 to A3) May-Grünwald-Giemsa staining of kidney marrow smears for $t e t 2^{w t / w t}$ fish shows no defects in maturation or the morphology of the blood cells. (B1 to B3) May-Grünwald-Giemsa staining of tet $2^{w t / m}$ kidney marrow smears shows normal morphology of mature erythrocytes and mature myeloid and hematopoietic progenitor cells (6 of 10) (B1 and B2), as well as dysplastic myeloid and progenitor cells (4 of 10) (B2 and B3), in a subset of $t e t 2^{w t / m}$ fish. The erythrocyte lineage in the tet $2^{w t / m}$ mutants (4 of 10) (B2 and B3) also shows morphological differences compared with tet $2^{\text {wt } / w t}$ erythrocytes. (C1 to C3) May-Grünwald-Giemsa staining of kidney marrow smears for tet $2^{\mathrm{m} / \mathrm{m}}$ erythrocytes (10 of 10) shows dysplasia in the myeloid and progenitor cell lineages; also, the erythrocytes have a dark basophilic cytoplasm compared with tet $2^{w t / w t}$ erythrocytes. Red arrows, mature erythrocytes; orange arrows, progenitor cells; black arrows, mature myeloid cells; green arrow, eosinophil; asterisks, dysplastic myeloid cells.

zebrafish animal model. Furthermore, MGG staining of peripheral blood smears from 24-month-old tet $2^{m / m}$ fish showed that the erythrocytes in the tet $2^{m / m}$ fish exhibited an aberrant rounded shape compared with the characteristic flattened elliptical shape observed in the tet2 ${ }^{\text {wt/wt }}$ fish (Fig. 10E to G). This phenotype was accompanied by a significant increase in the cytoplasm-to-nucleus ratio, which indicates an arrest in maturation within circulating erythrocytes in $t e t 2^{m / m}$ fish (Fig. 10E), consistent with the development of MDS.

\section{DISCUSSION}

In patients with hematopoietic malignancies such as MDS, TET2 disruption affects global genomic methylation due to a deficiency in 5-methylcytosine dioxygenation in hematopoietic cells that modifies the epigenetic landscape of the tumor cells. In the last few years, several mouse models with targeted disruption of Tet 2 in the hematopoietic system have been reported, and they have been used to study the role of Tet2-inactivating mutations in normal hematopoietic cell development, the evolution of clonal dominance, and the development of hematopoietic malignancies. Tet2deficient mice predominantly developed CMML, followed by he- matopoietic malignancies, such as MDS and MPN (23-26). Similar to the results reported in murine models (23-26), the tet $2^{m / m}$ zebrafish we studied did not exhibit defects in embryonic hematopoiesis, remained viable and fertile, and developed clonal myelodysplasia of the kidney marrow as they aged, culminating in true MDS with anemia. At 24 months of age, tet2 zebrafish mutants develop increased percentages of progenitor cells and myelomonocytes and decreased percentages of erythrocyte lineage cells in the kidney marrow. In the peripheral blood, the 24month-old tet2 zebrafish mutants have anemia with erythroid cell dysplasia, indicating progression to MDS. This is consistent with clonal dominance with a bias toward myelomonocytic differentiation at the expense of erythroid differentiation in patients with TET2 mutations observed by Itzykson and coworkers (44).

Interestingly, in fish with heterozygous or homozygous loss of tet2, the nuclear $5 \mathrm{hmC}$ modification was selectively lost in the hematopoietic cells of the kidney marrow. Other tissues of the tet2 mutant fish, such as brain, muscle, and intestine, exhibited normal $5 \mathrm{hmC}$ levels, presumably due to compensation by Tet1 or Tet3, a finding that may not have been apparent in some of the murine models because of the use of vav-CRE to delete Tet 2 spe- 

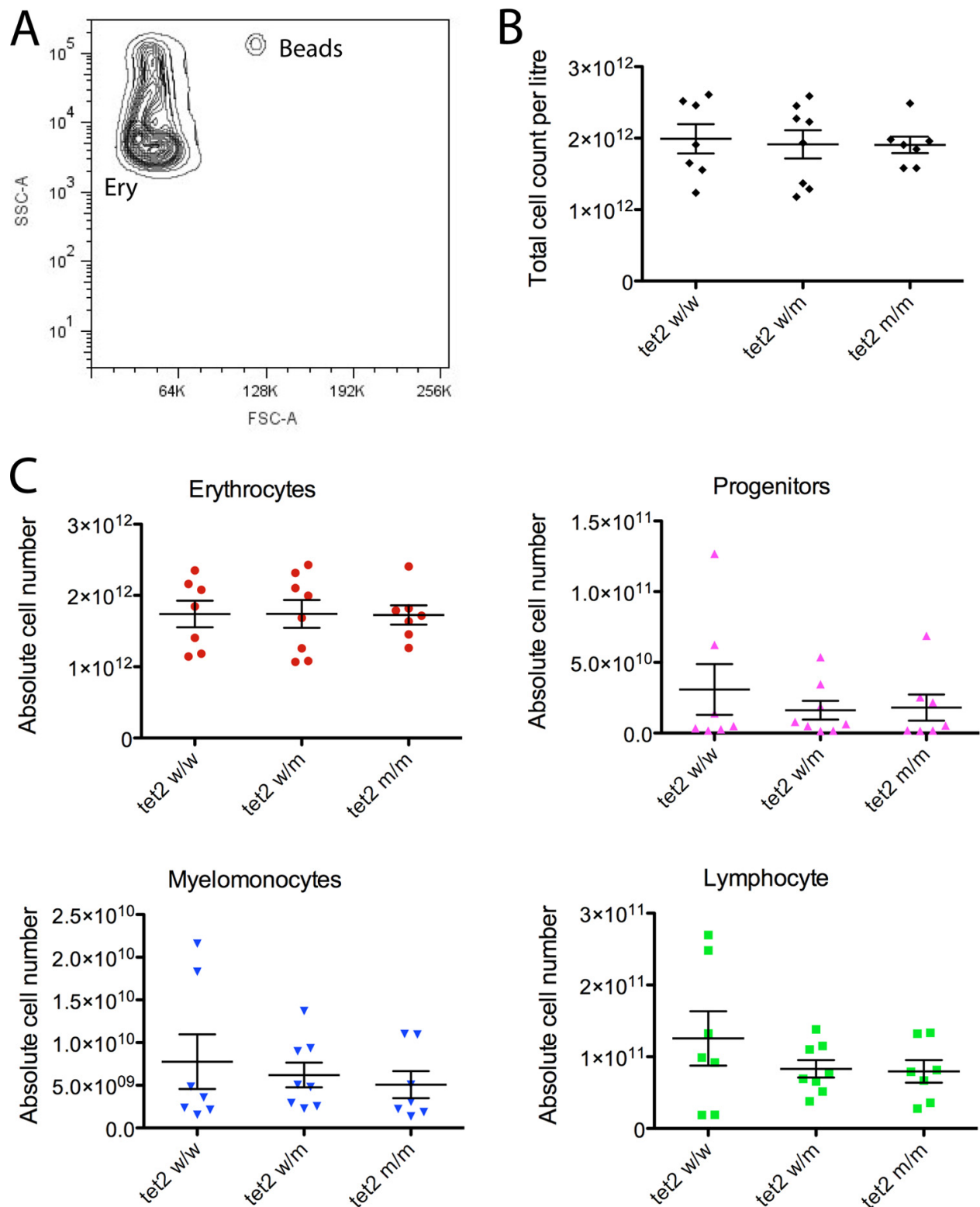

FIG 8 Analysis of total blood counts in $t e t 2^{w t / w t}$, tet $2^{w t / m}$, and $t e t 2^{m / m} 11$-month-old fish. (A) Representative schematic of the forward versus side scatter analysis plots for the peripheral blood populations in 11-month-old tet $2^{w t / w t}$, tet $2^{w t / m}$, and $t e t 2^{m / m}$ fish. (B) Analysis of the total peripheral blood counts for 11-month-old $t e t 2^{w t / w t}, t e t 2^{w t / m}$, and $t e t 2^{m / m}$ fish shows no significant differences among the three different genotypes. (C) Comparison of absolute cell numbers for erythrocytes, progenitor cells, myelomonocytes, and lymphocytes in the peripheral blood of 11 -month-old tet $2^{\text {wt } / w t}$, tet $2^{\text {wt/m }}$, and tet $2^{\mathrm{m} / \mathrm{m}}$ fish reveals no differences among the three genotypes. The short horizontal lines represent the error bars, and the long horizontal lines represent the mean values.

cifically in hematopoietic cells. We interpret our result to suggest that Tet 1 and Tet 3 can replace the activity of Tet 2 in nonhematopoietic tissues so that $5 \mathrm{hmC}$ levels appear normal in most tissues of tet 2 mutant animals. In contrast, Tet 2 appears to play a unique role in $5 \mathrm{hmC}$ formation in hematopoietic cells that cannot be compensated for by normal, or even increased, levels of expression of tet 1 and tet3 (Fig. 5). We believe this finding explains why TET2-inactivating mutations are selected only in hematopoietic malignancies and not in other tumor types. Recent studies have indicated that gain-of-function mutations in $I D H 1$ and $I D H 2$ enable the mutant proteins to disrupt the normal function of TET proteins (45). Both hematopoietic malignancies and gliomas can acquire IDH1-IDH2 gain-of-function mutations, but gliomas do not exhibit TET2 loss-of-function mutations. Presumably this is because other TET proteins are able to generate $5 \mathrm{hmC}$ in TET2 mutant glial cells but not TET2 mutant hematopoietic cells, while IDH1-IDH2 mutant proteins would be expected to interfere with the activities of all three TET proteins. Thus, our findings also explain the lack of TET2 mutations in gliomas, even though IDH1-IDH2 mutants appear to act by interfering with TET function (46).

Recently, the effect of tet 2 loss on embryonic zebrafish hematopoiesis was reported, based on morpholino-mediated tet2 knockdown in embryos, which led to inhibition of erythropoiesis, 
A

\section{Erythrocytes}

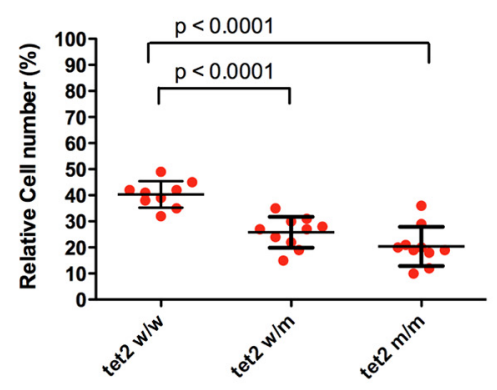

Progenitors

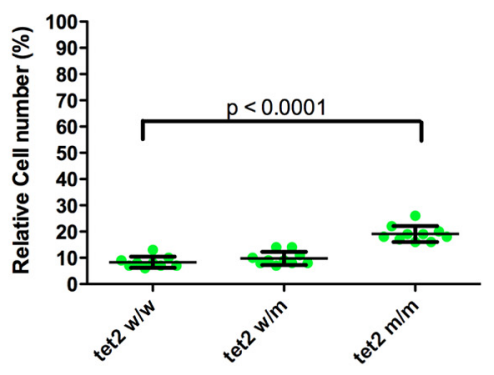

Lymphocytes

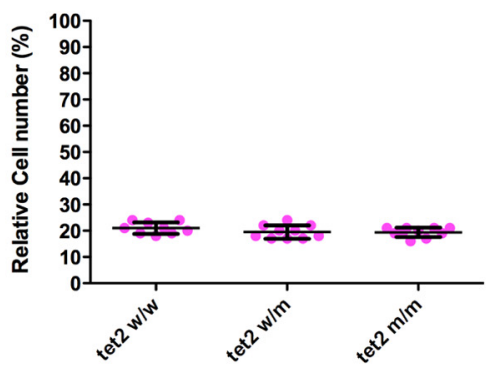

\section{Myelomonocytes}

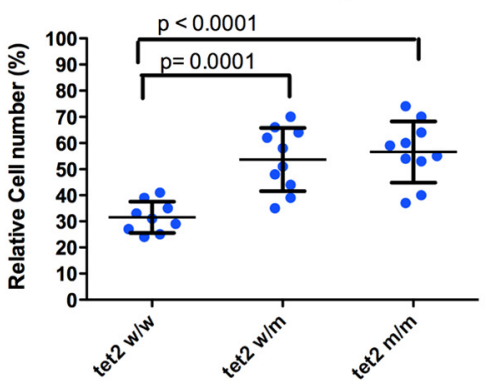

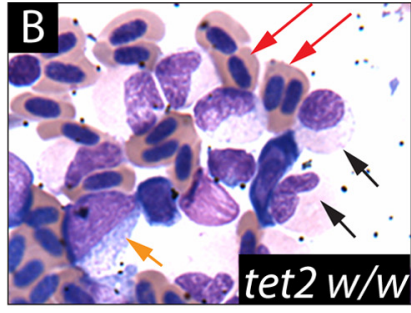
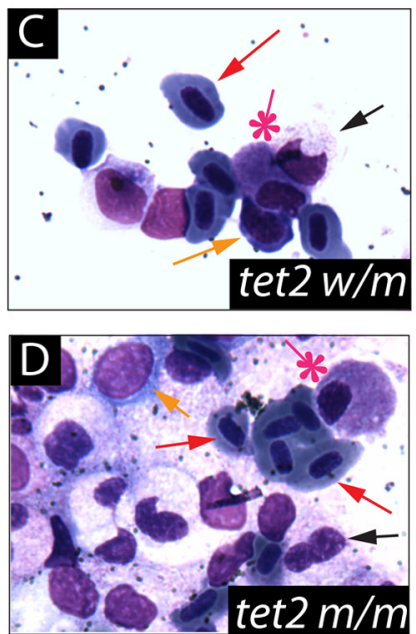

FIG 9 tet $2^{m / m}$ zebrafish develop MDS at 24 months of age. (A) Forward versus side scatter analysis plots for kidney marrow cell populations in 24-month-old tet $2^{w t / w t}, t e t 2^{w t / m}$, and $t e t 2^{m / m}$ fish. Analysis of the kidney marrow cell populations of 24-month-old fish with loss of tet2 shows a significant decrease in erythrocytes and a significant increase in the myelomonocyte population in $t e t 2^{w t / m}$ and $t e t 2^{\mathrm{m} / \mathrm{m}}$ fish compared with $t e t 2^{w t / w t}$ fish. A significant increase in the progenitor cell population is observed only in the tet $2^{m / m}$ fish. (B to D) May-Grünwald-Giemsa staining of kidney marrow smears at the 24 -month-old stage for $t e t 2^{w t / w t}(\mathrm{~B}), t e t 2^{w t / m}(\mathrm{C})$, and $t e t 2^{m / m}$ (D) fish shows the presence of dysplastic myeloid and progenitor cells and the presence of the basophilic cytoplasm in a subset of $t e t 2^{w t / m}$ fish and all $t e t 2^{m / m}$ fish. Red arrows, mature erythrocytes; orange arrows, progenitor cells; black arrows, mature myeloid cells; asterisks, dysplastic myeloid cells.

apparently due to loss of hematopoietic cells expressing the $s c l$, gata-1, and cmyb genes (40). In contrast, in our homozygous tet2 loss-of-function zebrafish mutant embryos, we did not observe any changes in HSPC numbers, as reflected by cmyb and CD41 expression, or any defects in embryonic erythropoiesis or in myeloperoxidase-expressing myeloid cells. Our results are consistent with those in most murine models, in which hematopoiesis is normal until 8 months of age, and in fact, homozygous Tet $2 \mathrm{mu}-$ tant HSCs exhibit an advantage in competitive repopulation after stem cell transplantation (23-26). An exception is the work in murine models of Kunimoto and colleagues (47), who report that Tet2 disruption leads to enhanced self-renewal and altered differentiation of fetal liver hematopoietic stem cells in mice harboring a LacZ gene trap cassette within exon 2 of the murine Tet2 gene. In this mouse line, the homozygous disruption of Tet 2 also results in perinatal lethality. These results are quite unique, in that most murine knockout lines and our tet $2^{m / m}$ zebrafish are viable and fertile and lack evidence of defects in embryonic and larval hematopoiesis.

We suspect that abnormalities of primitive erythropoiesis observed in the study of Ge and colleagues (40) after morpholino knockdown of tet 2 may reflect, at least in part, the nonspecific activation of $p 53$ by the morpholino (48). It is well known that morpholinos can produce spurious phenotypes through this mechanism, and most investigators now confirm the specificity of phenotypes in morphants by either repeating the knockdown in $p 53 \mathrm{~m} / \mathrm{m}$ embryos or simultaneously knocking down $p 53(31,49)$. This does not appear to have been done in the study by Ge et al. (40), providing an additional example of morphant phenotypes that may not accurately reflect the specific role of the gene under investigation.

It is possible that residual truncated protein expressed in our zebrafish mutant retains scaffolding or other activity that restores a normal embryonic hematopoiesis phenotype, but we strongly advise that interested investigators test additional tet2 zebrafish mutants generated by genome editing before performing additional studies based on morpholino knockdown of Tet2 (50).

It is interesting that both wild-type and $t e t 2^{\mathrm{m} / \mathrm{m}}$ fish lacked $5 \mathrm{hmC}$ expression in myb-GFP-positive cells in the AGM at $36 \mathrm{~h}$ p.f. (Fig. 3A2 to A7) and that $5 \mathrm{hmC}$ was expressed in corresponding MYB-negative cells in the ICM (Fig. $3 \mathrm{~A} 3$ and A6). The $5 \mathrm{hmC}^{+}$ cells in the ICM correspond to GATA ${ }^{+}$cells in the same region in an RFP line, although we have not been able to locate a suitable antibody to precisely demonstrate colabeling of these cells with both GATA and 5hmC. We think that this finding is consistent with the interpretation that the $5 \mathrm{hmC}$ modification becomes necessary to upregulate the expression of differentiation-specific genes as HSPCs begin to give rise to different blood cell lineages during hematopoiesis. In early hematopoietic cells of the ICM and CHT, however, it appears that Tet 1 or Tet 3 can replace the activity of Tet2, and apparently this redundancy is lost as the cells migrate to the kidney marrow (Fig. 3A1, A2, and A3). We have shown that 
A

Erythrocytes

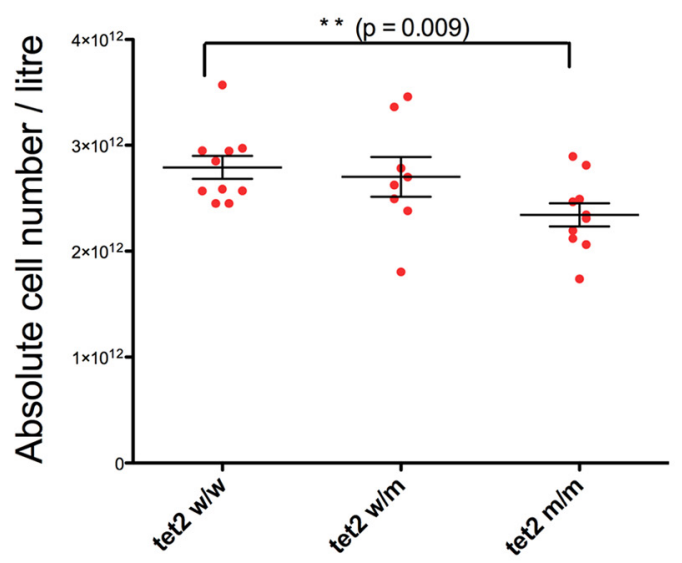

C

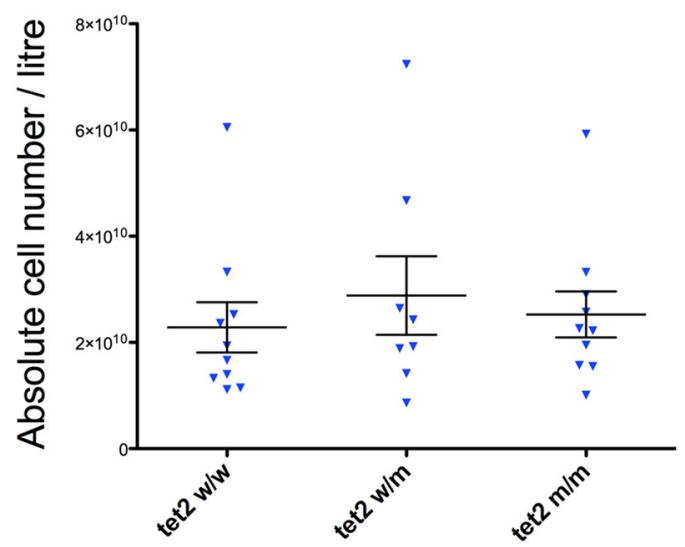

B

Progenitors

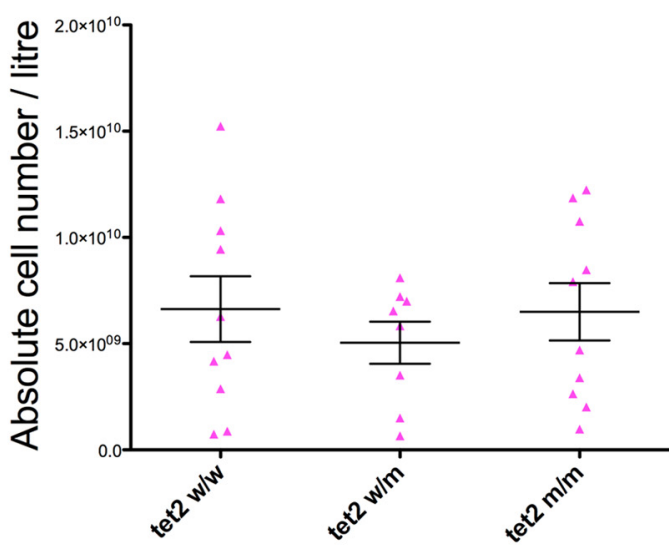

D Lymphocytes

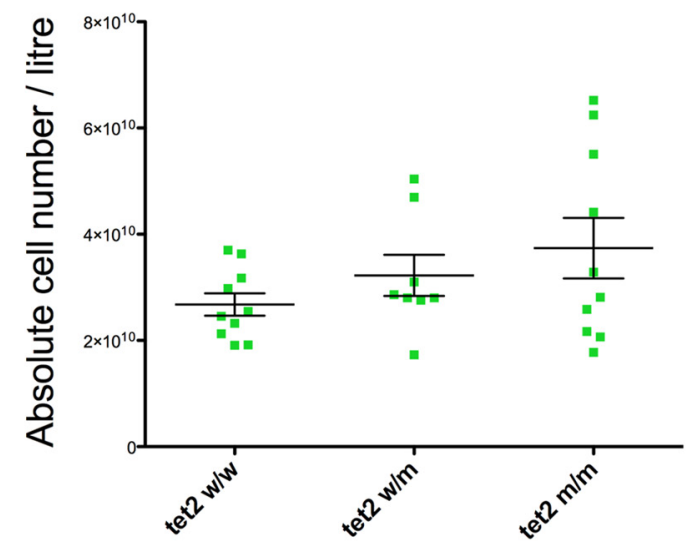

$\mathrm{E}$
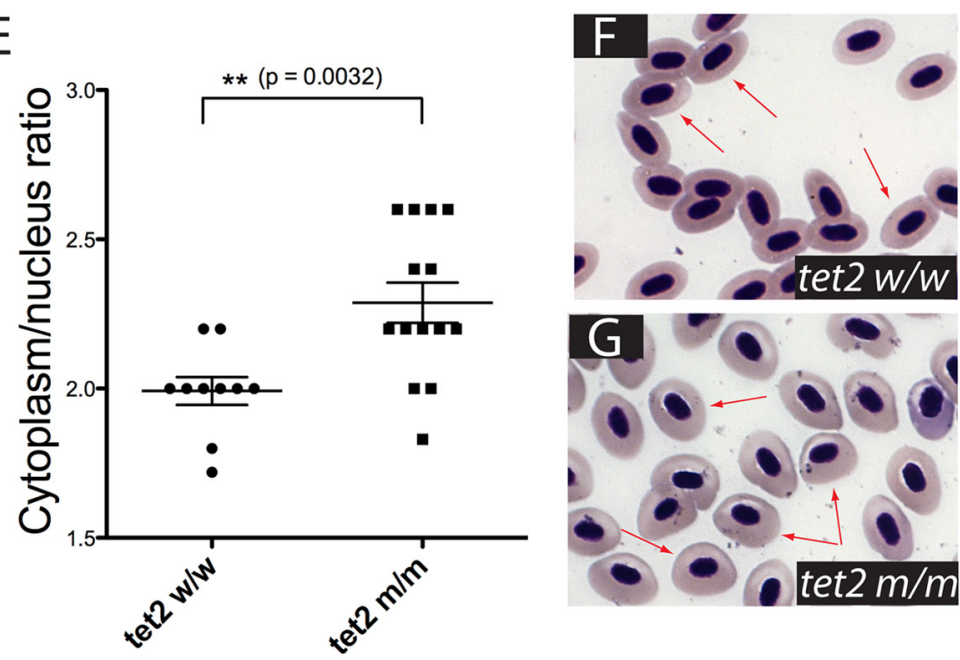

FIG 10 Analysis of total blood count in $t e t 2^{w t / w t}, t e t 2^{w t / m}$, and tet $2^{m / m} 24$-month-old fish. (A to D) Comparison of absolute cell numbers for erythrocytes (A), progenitor cells (B), myelomonocytes (C), and lymphocytes (D) in the peripheral blood of 24-month-old tet $2^{w t / w t}$, tet $2^{w t / m}$, and tet $2^{m / m}$ fish reveals a decrease in the total number of erythrocytes but not the other blood cell types in the $t e t 2^{m / m}$ fish compared with tet $2^{w t / w t}$ fish. Statistical analysis was performed using an unpaired Student $t$ test. The long horizontal lines denote the mean values. (E) Scatter plot showing the cytoplasm/nucleus ratio of the circulating erythrocytes from 24-month-old tet $2^{w t / w t}$ and $t e t 2^{m / m}$ fish. Statistical analysis was performed using an unpaired Student $t$ test. The long horizontal lines denote the mean values. (F and G) Analysis of the peripheral blood smears by MGG staining reveals a difference in the morphology of the erythrocytes between 24-month-old tet $2^{w t / w t}(\mathrm{~F})$ and $t e t 2^{m / m}(\mathrm{G})$ fish. 
the tet 1 and tet 3 mRNAs are expressed in kidney marrow hematopoietic cells, and thus, further work is needed to identify the underlying mechanisms that make Tet 1 and Tet 3 unable to function in place of Tet 2 in the kidney marrow cells of juvenile and adult fish.

It has been known for years that about $10 \%$ of people over 50 years of age and $20 \%$ over 80 years develop clonal skewing of hematopoiesis, particularly within the myeloid lineages. Very recent studies have shown that in $\sim 6 \%$ of these individuals, this clonal advantage is imparted by somatically acquired inactivating mutations of TET2, leading to enhanced self-renewal and clonal dominance of the HSCs that acquire TET2 mutations (16). Even though these individuals have clonal hematopoiesis, their circulating blood cell counts may remain normal for prolonged periods. An attractive possibility is that nontoxic drugs could be identified that are able to selectively suppress TET2 mutant hematopoietic stem cells and allow the return of normal polyclonal hematopoiesis in these individuals. It appears likely that TET2 loss-of-function mutations could represent the initial genetic hit in some cases of myeloid malignancies and that suppression of their self-renewal advantage might prevent the acquisition of additional mutations leading to myeloid malignancies, as proposed recently for DNMT3a mutations by Shlush and coworkers (51).

Our tet $2^{m / m}$ zebrafish develop premyelodysplasia at 11 months of age and MDS at 24 months of age. This model may prove particularly useful for identifying suppressors of tet 2 mutant hematopoietic cells, because the adult fish develop MDS. Embryos from the $t e t 2^{m / m}$ line are well suited for phenotype-based small-molecule drug screens and genetic screens to identify synthetic-lethal interactions with Tet2 loss in HSPCs. It is reassuring in this regard that our tet 2 mutant zebrafish provide a faithful model of progressive myelodysplasia with age that occurs in patients. It recapitulates important aspects of human myeloid disease, such as loss of $5 \mathrm{hmc}$ specifically in the blood cells, myeloid skewing, and clonal hematopoiesis culminating in MDS. Thus, this mutant line affords a powerful tool for analyzing the therapeutic effects of candidate small molecules and genes that are synthetic lethal with tet 2 loss in hematopoiesis and in the onset and progression of myelodysplasia.

\section{ACKNOWLEDGMENTS}

We thank Elspeth M. Payne, Alejandro Gutierrez, and Alex Kentsis for spirited discussions and encouragement. We thank Suneet Agarwal and Paula Fraenkel for their advice on experimental procedures. We also thank John Gilbert for editorial assistance and critical comments.

This work was supported by the National Cancer Institute, National Institutes of Health (grant R01 CA93152 to A.T.L.); by a Leukemia and Lymphoma Society Special Fellow Award (to E.G.); by an Alex's Lemonade Stand Foundation Young Investigator Award (to E.G.); by the Andrew McDonough B + Foundation (to E.G.); by an NIH Director's Pioneer Award (DP1 GM105378 to J.K.J.); by the National Institute of General Medical Science, NIH (R01 GM088040 to J.K.J.); and by the National Cancer Institute, NIH (T32 CA009216 to J.D.S.).

E.G. designed, performed, and analyzed the experiments. M.R.M. designed experiments. N.M., A.T.N., and M.K. performed experiments. Y.Y.K. and S.Y. analyzed data. J.D.S. and J.K.J. designed and assembled the engineered zinc finger nucleases. E.G. and A.T.L. designed the experiments and revised the manuscript.

J.K.J. is a consultant for Horizon Discovery and has financial interests in Editas Medicine and Transposagen Biopharmaceuticals. J.K.J.'s inter- ests were reviewed and are managed by Massachusetts General Hospital and Partners HealthCare in accordance with their conflict of interest policies. We declare that we have no other competing financial interests.

\section{REFERENCES}

1. He YF, Li BZ, Li Z, Liu P, Wang Y, Tang Q, Ding J, Jia Y, Chen Z, Li L, Sun Y, Li X, Dai Q, Song CX, Zhang K, He C, Xu GL. 2011. Tet-mediated formation of 5-carboxylcytosine and its excision by TDG in mammalian DNA. Science 333:1303-1307. http://dx.doi.org/10.1126 /science.1210944.

2. Pastor WA, Aravind L, Rao A. 2013. TETonic shift: biological roles of TET proteins in DNA demethylation and transcription. Nat Rev Mol Cell Biol 14:341-356. http://dx.doi.org/10.1038/nrm3589.

3. Wu H, Zhang Y. 2014. Reversing DNA methylation: mechanisms, genomics, and biological functions. Cell 156:45-68. http://dx.doi.org/10 .1016/j.cell.2013.12.019.

4. Bejar R, Stevenson K, Abdel-Wahab O, Galili N, Nilsson B, GarciaManero G, Kantarjian H, Raza A, Levine RL, Neuberg D, Ebert BL. 2011. Clinical effect of point mutations in myelodysplastic syndromes. N Engl J Med 364:2496-2506. http://dx.doi.org/10.1056/NEJMoa1013343.

5. Tefferi A, Lim KH, Abdel-Wahab O, Lasho TL, Patel J, Patnaik MM, Hanson CA, Pardanani A, Gilliland DG, Levine RL. 2009. Detection of mutant TET2 in myeloid malignancies other than myeloproliferative neoplasms: CMML, MDS, MDS/MPN and AML. Leukemia 23:1343-1345. http://dx.doi.org/10.1038/leu.2009.59.

6. Kosmider O, Gelsi-Boyer V, Cheok M, Grabar S, Della-Valle V, Picard F, Viguié F, Quesnel B, Beyne-Rauzy O, Solary E, Vey N, HunaultBerger M, Fenaux P, Mansat-De Mas V, Delabesse E, Guardiola P, Lacombe C, Vainchenker W, Preudhomme C, Dreyfus F, Bernard OA, Birnbaum D, Fontenay M. 2009. TET2 mutation is an independent favorable prognostic factor in myelodysplastic syndromes (MDSs). Blood 114:3285-3291. http://dx.doi.org/10.1182/blood-2009-04-215814.

7. Itzykson R, Kosmider O, Cluzeau T, Mansat-De Mas V, Dreyfus F, Beyne-Rauzy O, Quesnel B, Vey N, Gelsi-Boyer V, Raynaud S, Preudhomme C, Adès L, Fenaux P, Fontenay M. 2011. Impact of TET2 mutations on response rate to azacitidine in myelodysplastic syndromes and low blast count acute myeloid leukemias. Leukemia 25:1147-1152. http://dx.doi.org/10.1038/leu.2011.71.

8. Tefferi A, Pardanani A, Lim KH, Abdel-Wahab O, Lasho TL, Patel J, Gangat N, Finke CM, Schwager S, Mullally A, Li CY, Hanson CA, Mesa R, Bernard O, Delhommeau F, Vainchenker W, Gilliland DG, Levine RL. 2009. TET2 mutations and their clinical correlates in polycythemia vera, essential thrombocythemia and myelofibrosis. Leukemia 23:905911. http://dx.doi.org/10.1038/leu.2009.47.

9. Vannucchi AM, Lasho TL, Guglielmelli P, Biamonte F, Pardanani A, Pereira A, Finke C, Score J, Gangat N, Mannarelli C, Ketterling RP, Rotunno G, Knudson RA, Susini MC, Laborde RR, Spolverini A, Pancrazzi A, Pieri L, Manfredini R, Tagliafico E, Zini R, Jones A, Zoi K, Reiter A, Duncombe A, Pietra D, Rumi E, Cervantes F, Barosi G, Cazzola M, Cross NC, Tefferi A. 2013. Mutations and prognosis in primary myelofibrosis. Leukemia 27:1861-1869. http://dx.doi.org/10 .1038/leu.2013.119.

10. Nibourel O, Kosmider O, Cheok M, Boissel N, Renneville A, Philippe N, Dombret H, Dreyfus F, Quesnel B, Geffroy S, Quentin S, RocheLestienne C, Cayuela JM, Roumier C, Fenaux P, Vainchenker W, Bernard OA, Soulier J, Fontenay M, Preudhomme C. 2010. Incidence and prognostic value of TET2 alterations in de novo acute myeloid leukemia achieving complete remission. Blood 116:1132-1135. http://dx.doi .org/10.1182/blood-2009-07-234484.

11. Weissmann S, Alpermann T, Grossmann V, Kowarsch A, Nadarajah N, Eder C, Dicker F, Fasan A, Haferlach C, Haferlach T, Kern W, Schnittger S, Kohlmann A. 2012. Landscape of TET2 mutations in acute myeloid leukemia. Leukemia 26:934-942. http://dx.doi.org/10.1038/leu .2011 .326$.

12. Konstandin N, Bultmann S, Szwagierczak A, Dufour A, Ksienzyk B, Schneider F, Herold T, Mulaw M, Kakadia PM, Schneider S, Spiekermann K, Leonhardt H, Bohlander SK. 2011. Genomic 5-hydroxymethylcytosine levels correlate with TET2 mutations and a distinct global gene expression pattern in secondary acute myeloid leukemia. Leukemia 25: 1649-1652. http://dx.doi.org/10.1038/leu.2011.134.

13. Kosmider O, Delabesse E, de Mas VM, Cornillet-Lefebvre P, Blanchet O, Delmer A, Recher C, Raynaud S, Bouscary D, Viguié F, 
Lacombe C, Bernard OA, Ifrah N, Dreyfus F, Fontenay M. 2011. TET2 mutations in secondary acute myeloid leukemias: a French retrospective study. Haematologica 96:1059-1063. http://dx.doi.org/10 .3324/haematol.2011.040840.

14. Chou WC, Chou SC, Liu CY, Chen CY, Hou HA, Kuo YY, Lee MC, Ko BS, Tang JL, Yao M, Tsay W, Wu SJ, Huang SY, Hsu SC, Chen YC, Chang YC, Kuo YY, Kuo KT, Lee FY, Liu MC, Liu CW, Tseng MH, Huang CF, Tien HF. 2011. TET2 mutation is an unfavorable prognostic factor in acute myeloid leukemia patients with intermediate-risk cytogenetics. Blood 118:3803-3810. http://dx.doi.org/10.1182/blood-2011-02 $-339747$.

15. Ko M, Huang Y, Jankowska AM, Pape UJ, Tahiliani M, Bandukwala HS, An J, Lamperti ED, Koh KP, Ganetzky R, Liu XS, Aravind L, Agarwal S, Maciejewski JP, Rao A. 2010. Impaired hydroxylation of 5-methylcytosine in myeloid cancers with mutant TET2. Nature 468:839_ 843. http://dx.doi.org/10.1038/nature09586.

16. Busque L, Patel JP, Figueroa ME, Vasanthakumar A, Provost S, Hamilou Z, Mollica L, Li J, Viale A, Heguy A, Hassimi M, Socci N, Bhatt PK, Gonen M, Mason CE, Melnick A, Godley LA, Brennan CW, AbdelWahab O, Levine RL. 2012. Recurrent somatic TET2 mutations in normal elderly individuals with clonal hematopoiesis. Nat Genet 44:11791181. http://dx.doi.org/10.1038/ng.2413.

17. Moran-Crusio K, Reavie L, Shih A, Abdel-Wahab O, Ndiaye-Lobry D, Lobry C, Figueroa ME, Vasanthakumar A, Patel J, Zhao X, Perna F, Pandey S, Madzo J, Song C, Dai Q, He C, Ibrahim S, Beran M, Zavadil J, Nimer SD, Melnick A, Godley LA, Aifantis I, Levine RL. 2011. Tet2 loss leads to increased hematopoietic stem cell self-renewal and myeloid transformation. Cancer Cell 20:11-24. http://dx.doi.org/10.1016/j.ccr .2011.06.001.

18. Ko M, Bandukwala HS, An J, Lamperti ED, Thompson EC, Hastie R, Tsangaratou A, Rajewsky K, Koralov SB, Rao A. 2011. Ten-ElevenTranslocation 2 (TET2) negatively regulates homeostasis and differentiation of hematopoietic stem cells in mice. Proc Natl Acad Sci U S A 108: 14566-14571. http://dx.doi.org/10.1073/pnas.1112317108.

19. Li Z, Cai X, Cai CL, Wang J, Zhang W, Petersen BE, Yang FC, Xu M. 2011. Deletion of Tet2 in mice leads to dysregulated hematopoietic stem cells and subsequent development of myeloid malignancies. Blood 118: 4509-4518. http://dx.doi.org/10.1182/blood-2010-12-325241.

20. Quivoron C, Couronné L, Della Valle V, Lopez CK, Plo I, WagnerBallon O, Do Cruzeiro M, Delhommeau F, Arnulf B, Stern MH, Godley L, Opolon P, Tilly H, Solary E, Duffourd Y, Dessen P, Merle-Beral H, Nguyen-Khac F, Fontenay M, Vainchenker W, Bastard C, Mercher T, Bernard OA. 2011. TET2 inactivation results in pleiotropic hematopoietic abnormalities in mouse and is a recurrent event during human lymphomagenesis. Cancer Cell 20:25-38. http://dx.doi.org/10.1016/j.ccr.2011.06 .003 .

21. North TE, Goessling W, Walkley CR, Lengerke C, Kopani KR, Lord AM, Weber GJ, Bowman TV, Jang IH, Grosser T, Fitzgerald GA, Daley GQ, Orkin SH, Zon LI. 2007. Prostaglandin E2 regulates vertebrate hematopoietic stem cell homeostasis. Nature 447:1007-1011. http://dx .doi.org/10.1038/nature05883.

22. Goessling W, Allen RS, Guan X, Jin P, Uchida N, Dovey M, Harris JM, Metzger ME, Bonifacino AC, Stroncek D, Stegner J, Armant M, Schlaeger T, Tisdale JF, Zon LI, Donahue RE, North TE. 2011. Prostaglandin E2 enhances human cord blood stem cell xenotransplants and shows long-term safety in preclinical nonhuman primate transplant models. Cell Stem Cell 8:445-458. http://dx.doi.org/10.1016/j.stem.2011.02.003.

23. Cutler C, Multani P, Robbins D, Kim HT, Le T, Hoggatt J, Pelus LM, Desponts C, Chen YB, Rezner B, Armand P, Koreth J, Glotzbecker B, Ho VT, Alyea E, Isom M, Kao G, Armant M, Silberstein L, Hu P, Soiffer RJ, Scadden DT, Ritz J, Goessling W, North TE, Mendlein J, Ballen K, Zon LI, Antin JH, Shoemaker DD. 2013. Prostaglandin-modulated umbilical cord blood hematopoietic stem cell transplantation. Blood 122: 3074-3081. http://dx.doi.org/10.1182/blood-2013-05-503177.

24. Bolli N, Payne EM, Rhodes J, Gjini E, Johnston AB, Guo F, Lee JS, Stewart RA, Kanki JP, Chen AT, Zhou Y, Zon LI, Look AT. 2011. cpsf1 is required for definitive HSC survival in zebrafish. Blood 117:3996-4007. http://dx.doi.org/10.1182/blood-2010-08-304030.

25. Payne EM, Bolli N, Rhodes J, Abdel-Wahab OI, Levine R, Hedvat CV, Stone R, Khanna-Gupta A, Sun H, Kanki JP, Gazda HT, Beggs AH, Cotter FE, Look AT. 2011. Ddx18 is essential for cell-cycle progression in zebrafish hematopoietic cells and is mutated in human AML. Blood 118: 903-915. http://dx.doi.org/10.1182/blood-2010-11-318022.
26. Chen W, Dailey HA, Paw BH. 2010. Ferrochelatase forms an oligomeric complex with mitoferrin-1 and Abcb10 for erythroid heme biosynthesis. Blood 116:628-630. http://dx.doi.org/10.1182/blood-2009-12-259614.

27. Shah DI, Takahashi-Makise N, Cooney JD, Li L, Schultz IJ, Pierce EL, Narla A, Seguin A, Hattangadi SM, Medlock AE, Langer NB, Dailey TA, Hurst SN, Faccenda D, Wiwczar JM, Heggers SK, Vogin G, Chen W, Chen C, Campagna DR, Brugnara C, Zhou Y, Ebert EL, Danial NN, Fleming MD, Ward DM, Campanella M, Dailey HA, Kaplan J, Paw BH. 2012. Mitochondrial Atpif1 regulates heme synthesis in developing erythroblasts. Nature 491:608-612. http://dx.doi.org/10.1038/nature11536.

28. Sood R, English MA, Belele CL, Jin H, Bishop K, Haskins R, McKinney MC, Chahal J, Weinstein BM, Wen Z, Liu PP. 2010. Development of multilineage adult hematopoiesis in the zebrafish with a runxl truncation mutation. Blood 115:2806-2809. http://dx.doi.org/10.1182/blood-2009 $-08-236729$.

29. Pase L, Layton JE, Kloosterman WP, Carradice D, Waterhouse PM, Lieschke GJ. 2009. miR-451 regulates zebrafish erythroid maturation in vivo via its target gata2. Blood 113:1794-1804. http://dx.doi.org/10.1182 /blood-2008-05-155812.

30. Keightley MC, Layton JE, Hayman JW, Heath JK, Lieschke GJ. 2011. Mediator subunit 12 is required for neutrophil development in zebrafish. PLoS One 6 e23845. http://dx.doi.org/10.1371/journal.pone.0023845.

31. Bolli N, Payne EM, Grabher C, Lee JS, Johnston AB, Falini B, Kanki JP, Look AT. 2010. Expression of the cytoplasmic NPM1 mutant (NPMc+) causes the expansion of hematopoietic cells in zebrafish. Blood 115:33293340. http://dx.doi.org/10.1182/blood-2009-02-207225.

32. North TE, Goessling W, Peeters M, Li P, Ceol C, Lord AM, Weber GJ, Harris J, Cutting CC, Huang P, Dzierzak E, Zon LI. 2009. Hematopoietic stem cell development is dependent on blood flow. Cell 137:736-748. http://dx.doi.org/10.1016/j.cell.2009.04.023.

33. Murayama E, Kissa K, Zapata A, Mordelet E, Briolat V, Lin HF, Handin RI, Herbomel P. 2006. Tracing hematopoietic precursor migration to successive hematopoietic organs during zebrafish development. Immunity 25:963-975. http://dx.doi.org/10.1016/j.immuni.2006.10.015.

34. Westerfield M. 2000. The zebrafish book: a guide for the laboratory use of zebrafish (Danio rerio), 4th ed. University of Oregon Press, Eugene, OR.

35. Sander JD, Yeh JR, Peterson RT, Joung JK. 2011. Engineering zinc finger nucleases for targeted mutagenesis of zebrafish. Methods Cell Biol 104:5158. http://dx.doi.org/10.1016/B978-0-12-374814-0.00003-3.

36. Sander JD, Dahlborg EJ, Goodwin MJ, Cade L, Zhang F, Cifuentes D, Curtin SJ, Blackburn JS, Thibodeau-Beganny S, Qi Y, Pierick CJ, Hoffman E, Maeder ML, Khayter C, Reyon D, Dobbs D, Langenau DM, Stupar RM, Giraldez AJ, Voytas DF, Peterson RT, Yeh JR, Joung JK. 2011. Selection-free zinc-finger-nuclease engineering by contextdependent assembly (CoDA). Nat Methods 8:67-69. http://dx.doi.org/10 $.1038 /$ nmeth. 1542 .

37. Almeida RD, Loose M, Sottile V, Matsa E, Denning C, Young L, Johnson $\mathrm{AD}$, Gering M, Ruzov A. 2012. 5-Hydroxymethyl-cytosine enrichment of non-committed cells is not a universal feature of vertebrate development. Epigenetics 7:383-389. http://dx.doi.org/10.4161/epi.19375.

38. Traver D, Paw BH, Poss KD, Penberthy WT, Lin S, Zon LI. 2003. Transplantation and in vivo imaging of multilineage engraftment in zebrafish bloodless mutants. Nat Immunol 4:1238-1246. http://dx.doi.org /10.1038/ni1007.

39. Langemeijer SM, Kuiper RP, Berends M, Knops R, Aslanyan MG, Massop M, Stevens-Linders E, van Hoogen P, van Kessel AG, Raymakers RA, Kamping EJ, Verhoef GE, Verburgh E, Hagemeijer A, Vandenberghe P, de Witte T, van der Reijden BA, Jansen JH. 2009. Acquired mutations in TET2 are common in myelodysplastic syndromes. Nat Genet 41:838-842. http://dx.doi.org/10.1038/ng.391.

40. Ge L, Zhang RP, Wan F, Guo DY, Wang P, Xiang LX, Shao JZ. 2014. TET2 plays an essential role in erythropoiesis by regulating lineagespecific genes via DNA oxidative demethylation in a zebrafish model. Mol Cell Biol 34:989-1002. http://dx.doi.org/10.1128/MCB.01061-13.

41. Abdel-Wahab O, Mullally A, Hedvat C, Garcia-Manero G, Patel J, Wadleigh M, Malinge S, Yao J, Kilpivaara O, Bhat R, Huberman K, Thomas S, Dolgalev I, Heguy A, Paietta E, Le Beau MM, Beran M, Tallman MS, Ebert BL, Kantarjian HM, Stone RM, Gilliland DG, Crispino JD, Levine RL. 2009. Genetic characterization of TET1, TET2, and TET3 alterations in myeloid malignancies. Blood 114:144-147. http: //dx.doi.org/10.1182/blood-2009-03-210039.

42. Huang Y, Chavez L, Chang X, Wang X, Pastor WA, Kang J, ZepedaMartínez JA, Pape UJ, Jacobsen SE, Peters B, Rao A. 2014. Distinct roles 
of the methylcytosine oxidases Tet1 and Tet2 in mouse embryonic stem cells. Proc Natl Acad Sci U S A 111:1361-1366. http://dx.doi.org/10.1073 /pnas.1322921111.

43. Hon GC, Song CX, Du T, Jin F, Selvaraj S, Lee AY, Yen CA, Ye Z, Mao SQ, Wang BA, Kuan S, Edsall LE, Zhao BS, Xu GL, He C, Ren B. 2014. $5 \mathrm{mC}$ oxidation by Tet 2 modulates enhancer activity and timing of transcriptome reprogramming during differentiation. Mol Cell 56:286-297. http://dx.doi.org/10.1016/j.molcel.2014.08.026.

44. Itzykson R, Kosmider O, Renneville A, Morabito M, Preudhomme C, Berthon C, Adès L, Fenaux P, Platzbecker U, Gagey O, Rameau P, Meurice G, Oréar C, Delhommeau F, Bernard OA, Fontenay M, Vainchenker W, Droin N, Solary E. 2013. Clonal architecture of chronic myelomonocytic leukemias. Blood 121:2186-2198. http://dx.doi.org/10 .1182/blood-2012-06-440347.

45. Figueroa ME, Abdel-Wahab O, Lu C, Ward PS, Patel J, Shih A, Li Y, Bhagwat N, Vasanthakumar A, Fernandez HF, Tallman MS, Sun Z, Wolniak K, Peeters JK, Liu W, Choe SE, Fantin VR, Paietta E, Löwenberg B, Licht JD, Godley LA, Delwel R, Valk PJ, Thompson CB, Levine RL, Melnick A. 2010. Leukemic IDH1 and IDH2 mutations result in a hypermethylation phenotype, disrupt TET2 function, and impair hematopoietic differentiation. Cancer Cell 18:553-567. http://dx.doi.org/10 $.1016 /$ j.ccr.2010.11.015.

46. Losman JA, Looper RE, Koivunen P, Lee S, Schneider RK, McMahon C, Cowley GS, Root DE, Ebert BL, Kaelin WG, Jr. 2013. (R)-2- hydroxyglutarate is sufficient to promote leukemogenesis and its effects are reversible. Science 339:1621-1625. http://dx.doi.org/10.1126/science .1231677 .

47. Kunimoto H, Fukuchi Y, Sakurai M, Sadahira K, Ikeda Y, Okamoto S, Nakajima H. 2012. Tet2 disruption leads to enhanced self-renewal and altered differentiation of fetal liver hematopoietic stem cells. Sci Rep 2:273. http://dx.doi.org/10.1038/srep00273.

48. Robu ME, Larson JD, Nasevicius A, Beiraghi S, Brenner C, Farber SA, Ekker SC. 2007. p53 activation by knockdown technologies. PLoS Genet 3 e78. http://dx.doi.org/10.1371/journal.pgen.0030078.

49. Robu ME, Zhang Y, Rhodes J. 2012. Rereplication in emil-deficient zebrafish embryos occurs through a Cdh1-mediated pathway. PLoS One 7 e47658. http://dx.doi.org/10.1371/journal.pone.0047658.

50. Schulte-Merker S, Stainier DY. 2014. Out with the old, in with the new: reassessing morpholino knockdowns in light of genome editing technology. Development 141:3103-3104. http://dx.doi.org/10.1242/dev.112003.

51. Shlush LI, Zandi S, Mitchell A, Chen WC, Brandwein JM, Gupta V, Kennedy JA, Schimmer AD, Schuh AC, Yee KW, McLeod JL, Doedens M, Medeiros JJ, Marke R, Kim HJ, Lee K, McPherson JD, Hudson TJ, Pan-Leukemia Gene Panel Consortium HALT, Brown AM, Yousif F, Trinh QM, Stein LD, Minden MD, Wang JC, Dick JE. 2014. Identification of pre-leukaemic haematopoietic stem cells in acute leukaemia. Nature 506:328-333. http://dx.doi.org/10.1038/nature13038. 